NBER WORKING PAPERS SERIES

CONVERGENCE AND GROWTH LINKAGES BETWEEN NORTH AND SOUTH

John F. Helliwell

Alan Chung

Working Paper No. 3948

NATIONAL BUREAU OF ECONOMIC RESEARCH

1050 Massachusetts Avenue

Cambridge, MA 02138

January 1992

We are grateful for the research support of the Social Sciences and Humanities Research Council. An earlier version of this paper was presented at the OECD/KDI/Brookings/CEPR conference on modelling global interdependence, at the Korea Development Institute, Seoul, May 27-28, 1991. We are grateful to participants of the OECD/KDI/Brookings/CEPR conference, Seoul Korea, May 27-28, 1991, and especially Andrew Levin and Ralph Bryant, for comments on the first version of the paper. Thanks also to Susan Collins. Richard Cooper, Elhanan Helpman, Greg Mankiw and other members of the Harvard and NBER international economics seminars for comments on subsequent versions presented there. This paper is part of NBER's research program in Growth. Any opinions expressed are those of the authors and not those of the National Bureau of Economic Research. 
NBER Working Paper \#3948

January 1992

\title{
CONVERGENCE AND GROWTH LINKAGES BETWEEN NORTH AND SOUTH
}

\begin{abstract}
Using cross-sectional data for 98 countries for 1.960-85. this paper shows that growth of per capita GDP depends negatively on initial income levels, as implied by the convergence hypothesis, as well as on international differences in investment rates in physical and human capital. There is some evidence of slight economies of scale (1.06) among the industrial countries. The evidence in favour of the convergence hypothesis is strongest for the countries of the OECD and Latin America, and weakest for Asia. Growth in Latin America and Africa is lower than elsewhere even after allowing for international differences in initial income levels, scale, schooling and capital investment. Analysis of Solow residuals for the OECD countries (for which capital stock data are available) shows convergence in rates of technical progress, suggesting that convergence of per capita GDPs is not just a function of differences in investment rates. The linkage between per capita GDP and the real exchange rate is found to be strong for the OECD and Asia, weak for Africa and negative for Latin America.
\end{abstract}

John F. Helliwell

Center for International Affairs Room 403B

Harvard University 1737 Cambridge Street Cambridge, MA 02138 and NBER

\author{
Alan Chung \\ Department of Economics \\ University of British \\ Columbia \\ Vancouver, BC V6T 1W5 \\ CANADA
}




\section{INTRODUCTION}

In this paper we report some evidence on the longer term growth linkages ainong countries, especially between the industrialized and developing countries. Our starting point will be the fairly well established finding that there has been significant convergence in per capita growth rates among the industrialized countries over the thirty years since 1960', but little evidence of convergence between the industrialized and developing countries ${ }^{2}$. The central question we ask is: What are the conditions that appear to enable a country to enter a period of sustained growth that offers the prospect of convergence toward the income and productivity levels of the richer industrialized countries? Our tool for analysis will be an empirical framework explaining comparative growth performance over the $1960-85$ period in a way that allows simultaneously for convergence in per capita GDP, for possible returns to scale, and for international differences in investment rates in human and physical capital. We shall be especially on the look-out for evidence that the prospects for convergence differ by income level or region, or are characterized by possible threshold effects. We shall also be trying to assess

1 For some discussion of the evidence, see Abramovitz (1979, 1990), Baumol (1986), Dowrick and Nguyen (1989) and Maddison (1982).

${ }^{2}$ De Long (1988) suggests that the evidence for the richest countries may be due to sample selection bias. Other studies suggest that the evidence for the industrial countries is relatively robust to sample choice, but does not extend to the poorer countries, at least in terms of a simple negative correlation between starting values and subsequent growth of per capita incomes. See Baumol and Wolff (1988), Dowrick and Nguyen (1989), Baumol, Blackman and Wolff (1989), Chenery Robinson and Syrquin (1986) and Landes (1990). Factors advanced to explain the inability of many of the poorer countries to achieve the "social capability" (Abramovitz 1990) to "take off" (Rostow 1978) into sustained growth have included literacy (Rauch 1989), nutrition (Dasgupta 1991), high inflation rates (Gylfason 1990), poor macroeconomic policies (Fischer 1991), unequal wealth distribution (Alesina and Rodrick 1991) and education (Barro 1991, Romer 1989 and others). The evidence on the role of population growth is reviewed by Brander and Dowrick (1991). 
whether convergence in the growth rates of GDP per capita, to the extent it is taking place. is due entirely to higher investment rates in the countries catching up ${ }^{3}$, or is due to international transfers of technology that permit faster growth of efficiency levels in the initially poorer countries ${ }^{4}$.

The next section sets the stage by reviewing previous studies. Section 3 then presents our new results on convergence by income class and region, while the subsequent section deals with the important ancillary linkage between per capita GDP and real exchange rates. The concluding section sketches some possible inplications of these results for analyzing the linkages between North and South.

\section{SOME THEORY AND PREVIOUS RESULTS ON CONVERGENCE}

Our empirical analysis starts with an extended form of the Solow $(1956,1957)$ growth model, as augmented by Mankiw, Romer and Weil (1990) to include human capital accumulation, with real output determined as a Cobb-Douglas function of physical capital, human capital and efficiency units of labour:

'This is what is implied by the augmented Solow model used by Mankiw, Romer and Weil (1990), since in their model the technology index grows at the same rate in each country.

4 This possibility is central to the international convergence modelling in Helliwell and Chung (1988, 1990a, 1990b), since the variable being explained, in part by convergence, is the 'Solow residual' that already takes account of international differences in the rate of accunuluation of physical capital. 
(1) $Y(t)=K(t)^{\alpha} H(t)^{\mu}(A(t) L(t))^{1 \cdot \cdots \cdot \beta}$

where $H$ is the stock of human capital, $L$ the stock of labour (growing at rate $n$ ), $K$ the stock of physical capital and A the level of technology, growing at the constant $t^{5}$ rate $g$. The coefficients imply constant returns to all factors taken together, and hence diminishing returns to any combination of physical and human capital. If $s_{x}$ is the fraction of output invested in physical capital and $s_{h}$ the fraction invested in human capital. then in the steady state the log of output per capita is:

(2) $\ln [Y(t) / L(t)]=\ln A(0)+g t-((\alpha+\beta) /(1-\alpha-\beta)) \ln (n+g+\delta)$

$$
+(\alpha /(1-\alpha-\beta)) \ln \left(\S_{k}\right)+(\beta /(1-\alpha-\beta)) \ln \left(s_{n}\right)
$$

This framework is extended to include the possibility of what Mankiw et al. call "conditional convergence", that if each country starts at some level of output that differs from its steady state value, there will be convergence towards the steady state growth path for that country. This need not imply that all countries have the same equilibrium level of income per capita (they argue that the level of $\mathrm{A}$ can be different across countries, based on variations in

\footnotetext{
${ }^{5}$ The assumption of a constant growth rate for the technology index marks an important distinction between the Mankiw et al. framework and the one we have employed earlier using a mixture of timeseries and cross-sectional data to explain international differences in growth rates of productivity. In our framework (as developed and tested in Helliwell, Sturm and Salou. 1985. Helliwell and Chung, 1988, 1990a, 1990b, and Hansson and Helliwell, 1990) there is international convergence in the rate of growth of technical progress. We make some tests of this assumption against the alternative of constant technical progress, especially in Helliwell and Chung (1988, 1990a), and find significant rejection of the constant growth assumption. Our results are also consistent with those of Bernard and Durlauf (1991), who find time series evidence that series for output per capita in the industrial countries do not have the same stochastic trends. However, for purely cross-sectional work, as long as we are dealing with per capita GDP rather than Solow residuals, there is no uperational distinction in the functional forms to be estimated, so we make use of the Mankiw of al. simplifying assumption in our exposition here.
} 
natural resources, institutions, and other factors unrelated to the stocks of human and physical capital) or even the same growth rate, since the equilibrium growth rate for each country will depend on its population growth and investment in human and physical capital. The Solow model augmented for human capital accumulation predicts that the rate of convergence of each country towards its steady state growth path will be at the proportional rate $\lambda$, where

(3) $\lambda=(n+g+\delta)(1-\alpha-\beta)$.

The log difference between current income per effective worker and that in any given earlier period 0 is thus given by

(4) $\ln (y(t))-\ln (y(0))=\left(1-\mathrm{e}^{-\lambda l}\right)(\alpha /(1-\alpha-\beta)) \ln (\$)+\left(1-\mathrm{e}^{-\lambda l}\right)(\beta /(1-\alpha-\beta)) \ln \left(s_{h}\right)$

$-\left(1-\mathrm{e}^{-\lambda l}\right)((\alpha+\beta) /(1-\alpha-\beta)) \ln (\mathrm{n}+\mathrm{g}+\delta)-\left(1-\mathrm{e}^{-\lambda l}\right) \ln (\mathrm{y}(0))$.

Applied by Mankiw et al. to a cross-sectional sample of the growth experience of 98 countries from 1960 to 1985 , this equation seemed to fit the experience of the developing as well as the industrial countries. There was evidence of conditional convergence for the whole sample of countries, as well as for the more restricted sample of industrial countries. Their results also showed that allowing for the accumulation of human capital lowered the estimated coefficient on physical capital to a level that was consistent with capital's share in output, and hence with the Cobb-Douglas assunption of constant returns to scale. Mankiw ef al. interpreted their results as a vindication of the augmented Solow model, and an implicit rejection of the increasing 
number of models built on the assumption that knowledge spillovers created the likelihood of increasing returns to scale at the national level. ${ }^{n}$

The Mankiw et al model differs in a fundamental way from the one we have used earlier? to study convergence. In the Mankiw et al framework, the productivity index may have a different level in each country (to account for resource endowments, etc.), but has the same exogenous growth rate in each country. Although we used'a similar production structure to Mankiw et $\mathrm{al}^{8}$, we assumed that the efficiency indexes initially grow at different rates in each country, with convergence taking place in the rates of growth, and possibly in the levels, of the technology indexes. Thus international transfers of knowledge are given a central role in convergence, with the initially poorer countries able to have efficiency levels that grow faster than those in the initially richer countries. This is because the initially poorer countries are able to make use of current best practice procedures already in use in the more productive economies. If this approach is correct, it offers enhanced growth prospects for all countries that have the necessary conditions to be in the 'convergence club', since growth of per capita incomes can be

- For examples, see Romer (1986, 1990a, 1990b) and Lucas (1988, 1990). Alternative endogenous growth models by Grossman and Helpman $(1989,1990 \mathrm{a}, 1990 \mathrm{~b})$ assume economies of scale and knowledge spillovers at the industry level, which has no necessary implications for returns to scale at the national level. See Helpman (1991) for a helpful survey.

'In Helliwell Sturm and Salou (1985) and Helliwell and Chung (1991a) for the G-7, in Helliwell and Chung (1990a) for 19 industrial counties, and in Helliwell and Chung (1990b) for 19 industrial and 8 Asian economies.

- We have made use of a CES form, while they use Cobb-Douglas, but our elasticity of substitution is so close to 1.0 that our CES form has properties almost identical to the CobbDouglas. A potentially more important difference is that they account for international differences in human capital, while we did not do so in our earlier work. 
faster in the poorer countries without requiring higher levels of investment than in the richer countries, although of course that channel for convergence also remains available.

Because our earlier studies dealt with countries for which we were able to construct measures of the physical capital stock, we were able to obtain explicit measures of the 'Solow residuals', and to see whether they showed evidence of convergence. In our combined time series and cross-section studies, the results for the industrial countries provided strong evidence of international convergence of the growth rates of the Solow residuals ${ }^{10}$. Thus our results rejected quite strongly the assumption of an unchanging rate of technical progress ${ }^{11}$. However, it is possible that our rejection of constant technical progress, and our finding of international convergence in its growth rate, was due to the fact that our production function did not make explicit allowance for the growth of human capital. For example, if the countries with initially lower levels of productivity were also those with the highest rates of investment in human capital, then our measures of the Solow residual, which are derived from a production structure with only employment and physical capital, might appear to show productivity growth convergence where none really existed. To deal finally with that possibility, it will be necessary

\footnotetext{
9 The Solow residuals are obtained by inverting equation (1) to define a measured series for $A(t)$ using actual values for $Y$ and $K$, and using the number of employees to represent the labour input HL.

${ }^{10}$ Our results also showed rejection of long-term international equality of the levels of the efficiency indexes. Thus our experiments confirmed the Mankiw et al hypothesis that there are likely to be continuing international differences in the levels of the efficiency index.

"Our tests of the convergence model were against an alternative hypothesis of a countryspecific constant rate of technical progress. The data reject even more strongly the assumption of an unchanging rate of technical progress that is the same in each country. We also found some evidence (in Helliwell and Chung 1990a) that the growth of productivity indexes was faster in countries which had the fastest rates of growth in their openness to international trade, as measured by the ratio of exports to GDP.
} 
to develop some measures of variations over time in the level of human capital, to guard against the possibility that leaving out human capital growth is falsely suggesting international convergence of productivity growth rates. That is an important topic on our research agenda. However, for the present paper, we shall concentrate on estimating cross-sectional equations of the sort used by Mankiw et al., since they are also consistent with our preferred production structure. The difference lies in the interpretation of the constant term, which in the Mankiw er al. framework is just the logarithm of the ratio of equilibrium incomes. In our framework, the estimated constant term in a cross-sectional regression is a function of the equilibrium level differences as well as the speed of convergence of growth rates, and the initial level differences, of the productivity indexes. We shall also test more directly for convergence in the rates of growth of productivity indexes by using the more complete data available for the industrial countries.

An earlier paper (Helliwell 1991) used a framework rather like that of Mankiw et al. to consider whether there were some threshold levels of education below which convergence could not take place. The results suggested that there were no material threshold effects for education, and that the Mankiw et al. log-linear specification was roughly appropriate. That paper also added a direct test for economies of scale, and found some evidence of a low degree of scale economies for the industrial countries, with some possibility of lesser effects for the world sample as a whole. In a companion paper to this one (Helliwell and Chung 1991b), we extend the tests of economies of scale to see if they may apply over some range of country sizes, if not over the entire world sample, and compare the convergence process across countries with that applicable among regions within a given country. 


\section{CONVERGENCE RESULTS BY INCOME LEVEL AND REGION}

In this paper, we want to push harder on the tentative conclusion that the above model of conditional convergence, augmented further by the possibility of some returns to scale, is equally applicable to countries at all income levels. Our tests of the applicability of the model of conditional convergence to the developing countries will be based on dividing the sample by region as well as ordering it by average levels of income per capita: In this way we can see if it is true, as the Mankiw et al. global results seem to suggest, that the same model of convergence is equally applicable at all levels of development and in all parts of the world.

Our first result, as shown in Table 1, is a replication of the Mankiw et al. cross-sectional estimation of equation (4) explaining the 1960-1985 growth in real GDP per adult for 98 countries. The second equation imposes the parameter restrictions implied by equation (4), which are accepted quite easily, chiefly by means of shifting the weakly estimated coefficient on the final term. The third equation shows the effects of adding a variable measuring the average scale of each of the countries, being the log of the mean of each country's average real GDP per capita over the period from 1960 to $1985^{12}$. The final equation adds the

\footnotetext{
${ }^{12} \mathrm{An}$ earlier paper (Helliwell 1991) used the log of 1960 real GDP as the measure of scale, which gave sinaller and less significant estimates of the scale effects. Backus, Kehoe and Kehoe (1991) also use the log of initial GDP as their scale variable, and find no significant scale effects in the growth of GDP per capita (although they do find some scale effects in manufacturing). For an estimation covering a number of years, it makes a difference whether initial or average scale is used, and the theoretical preference must be for average scale, since it provides the appropriate discrete time analogue of a continuous time equation in which the growth rate depends on current relative scale. In addition, if there are errors of measurement in initial scale, they will be correlated to some extent with initial real GDP per adult, which appears negatively in the dependent variable. This will cause the estimate of the scale effect to be biased downward. Using end-of-sample scale would have the opposite effect, so that using the sample average serves to eliminate this source of bias if the errors in measurement are of approximately
} 
parameter restrictions, once again with little loss in goodness of fit or change in the key parameter estimates. All four equations show strong convergence effects, even though the industrial countries, the group for which convergence has previously been shown, make up less than one-quarter of the sample.

Mankiw et al treat the empirical success of their model, which assumes constant retums to scale, and has an investment coefficient small enough to be consistent with the augmented Solow model, as evidence that increasing returns to scale are not required to explain international differences in growth rates. However, by adding the scale variable, we provide a more direct test of the returns to scale assumption. The results suggest significant evidence of slight economies of scale, with each $10 \%$ increase in size being associated with an increase in the annual growth rate of $.062 / 25=.0025$, or $0.25 \%$. Our estimate of .062 for economies of scale is only one-sixth as large as suggested by the example calculations reported by Lucas (1990). We shall return later to a direct test of the Mankiw et al assumption of constant growth in the technical progress index. First we disaggregate the data sample by income class, to see if the new evidence of convergence applies equally to rich and poor countries.

The results are shown in Table 2, where the basic cross-sectional equation is repeated for each of four quartiles, separated according to their average levels of real GDP per adult for the 1960-1985 sample period. The most noteworthy feature of the results is that conditional convergence is stronger within each one of the income groupings than it is for the world as a whole, while all of the other variables are generally weaker within the groupings than

the same relative size over the sample period. 
for the world sample. Thus it would appear that some measure of economic closeness, as measured by income per capita, is helpful for defining groups of countries among which convergence is likely to take place. Within the income groupings, there appears to be little explanatory power in the schooling measure of human capital investment, little or no evidence of returns to scale, and modest impact from differing investment rates. Thus it would appear that these latter variables have more importance in explaining growth differences between the richer and poorer groups of countries than they do in explaining growth differences among countries with similar levels of income per capita. Subsidiary tests were run to see if the differences among the coefficients for different income classes are individually or collectively significant, as for a smaller sample of countries by Dowrick and Gemmell (1991). The only significant difference is in the constant terms, which are significantly lower for the lower income groups; once the separate constant terms are allowed for, permitting separate slope coefficients for any of the other variables does not significantly alter the results. ${ }^{13}$

${ }^{13}$ If the final equation of Table 1 is re-estimated with separate constant terms for each of the income quartiles, the pooled slope coefficients are as follows, with standard errors in brackets: scale .059 (.017); $\mathrm{cu}-.800(.062)$; investment $-(\mathrm{n}+\mathrm{g}+\mathrm{d}) .323(.057)$; school- $(\mathrm{n}+\mathrm{g}+\mathrm{d})$ $.079(.043)$. The constant term for the richest countries is $6.200(.602)$, from which the following terms are subtracted for the three poorer quartiles, respectively: $-.573(.086) ;-.940$ (.124); and $-1.58(.152)$. For the equation as a whole, the standard error of estimate drops from .317 to .212 , and the adjusted $\mathrm{R}^{2}$ rises from .495 to .775 with the addition of the quartile intercepts. The constraint that all slope coefficients are the same (relative to the case where they are different for each income class) is accepted easily $(p=.72)$. The sharp rise in the cu coefficient when the separate constant terms are admitted raises the possibility of econometric problems, since initial income used to define the starting point for convergence also enters negatively in the dependent variable, which is the log difference between real per capita GDP in 1960 and 1985. To test the possible size of this bias, the equation was estimated using instrumental variables with initial income renoved from the list of eligible instruments, replaced by the log average per capita GDP and a rank ordering of the same series. Average income avoids the econometric risk posed by initial income, since any bias caused by the negative correlation between initial income and growth would be offset by a corresponding positive correlation between growth and ending incone. As expected, this slightly lowers the convergence coefficient, to .624 (with standard error .068) in the equation with separate constant terms and to .203 (with standard error .068) in the equation with a single constant. These results 
Figures 1 through 4 show the relation between growth rates and initial income for each of the four groups of countries, where the growth rates are adjusted for differences in education, investment and scale, using the estimated coefficients in the final equation of Table $1^{14}$. The figures allow the outliers from the global regression plane to be identified, and hence may help to provide clues about some of the important dimensions that may be missing from our attempts to explain international differences in growth experience. It can be seen from the figures that the correlation between growth and GDP, after allowing for the estimated effects of education, investment and scale, is substantial for all four country groupings, but tighter for the two richer than for the two poorer quartiles ${ }^{15}$.

In Table 3, we examine the results by continent, to see whether geographic proximity is important in defining groups of countries among which convergence is expected to take place. For Latin America and the OECD, and to a slightly lesser extent Africa, convergence is significant and slightly larger than for the world sample, while there is no evidence of convergence in Asia. There appear to be no scale effects in any region except the OECD. Investment effects are largest and most significant in Asia, while schooling does not appear to

suggest even more strongly that the Mankiw et al specification, even when augmented by investment and schooling effects, does not fully capture the difference in the growth performance of the richest and poorest countries. Although, there is still no evidence of significant differences in the slope coefficients among the income classes, the significant differences in the constant terms raise the possibility of continuing medium-term divergence of growth rates between rich and poor countries.

${ }^{14}$ The adjustment is done by setting the investment, education and scale variables at sample average values when the hypothetical growth rates are calculated. The country residuals are then added to the predicted values to get the observations shown in the figures. We analyze the separate effects of scale in Helliwell and Chung (199lb).

${ }^{15}$ The correlation coefficients are -.836 and -.812 for Figures 1 and 2, compared to -.530 and -.778 for Figures 3 and 4 . 
have significant effects within any of the regions. More precise tests of regional differences are obtained by adding separate regional intercepts and slope coefficients to the 98 -country equation. Only the African and Latin American intercepts have t-values with absolute values greater than 1.0 , and both show slower growth than the global equation would predict. None of the slope coefficients are significantly different by region.

Figures 5 through 8 show on a regional basis the relationship between initial incomes and growth rates, once again after allowing for investment, education and scale effects using the coefficients from the restricted global equation in Table 1.

Figure 5 shows relatively weak convergence among the African countries, with South Africa a clear outlier in having more growth than its high initial income would predict. The slow growers, relative to predicted, were Zaire, Ghana and Zambia, perhaps reflecting their dependence on primary exports ${ }^{16}$.

Figure 6 shows clearly the relative lack of success of the convergence model as applied to Asia, with Hong Kong and Singapore growing much faster than convergence would suggest, and India much slower. Without those three countries, the remainder would support a negative relationship, once account was taken of differences in investment, education and scale

\footnotetext{
${ }^{16}$ Aside from the general decline in the export prospects for these commodities over the 1960-1985 period, there is also the possibility, raised by Eswaran and Kotwal (1989), that expanding trade between exporters of land-intensive primary products and exporters of labourintensive manufactured goods may reduce the real wages of the former in such a way as to give them lower per capita GDP.
} 
effects ${ }^{17}$. Figure 7 shows relatively strong convergence effects for Latin America, with no major exceptions evident.

From Figure 8 for the industrial countries, it can be seen that the strong convergence effect is not simply due to the experience of Japan, since there is a substantial number of countries spread over the range of growth rates and initial per-adult levels of real GDP. It is noteworthy that two of the countries with the lowest growth rates, relative to the predicted values, are Australia and New Zealand. This is what we would expect, since both are countries which derived a large fraction of their 1960 incomes from pastoral and other land-intensive activities whose terms of trade and relative activity levels suffered over the subsequent 25 years. A similar natural resource effect, but with the opposite sign, is provided by Norway, whose oil wealth was discovered, developed, and brought into full production during the 25-year period.

Comparing Figures 5 through 8, it is apparent that convergence applies much more closely to the growth experiences of Latin America and the OECD than to Africa and Asia, even after allowing for differences in investment, education, and scale. The need for additional explanatory factors is especially obvious in the case of Asia, where the correlation between initial income and subsequent growth is not even of the expected sign ${ }^{18}$.

${ }^{17}$ If Hong Kong, Singapore and India are removed from the sample, the correlation between initial income and adjusted growth is -.671 for the remaining countries.

18 The correlation between initial income and growth, after allowing for the estimated effects of other variables, is -.417 for Africa, and +.292 for $\wedge$ sia, compared to -.823 for Latin Anerica and -.862 for the OECD. 
Looking at the results from Tables 2 and 3 together, it would appear that the convergence results are more robust by region and income grouping than are those for education, investment, and scale. Conversely, it would appear that adding these latter variables, and especially education and investment, is important for explaining the growth variations among regions, and between the richest and the poorest countries.

We now turn, in Table 4, to attempt a more direct test of whether technical progress grows at the same constant rate in each country, as supposed by Mankiw et al, or whether it grows faster in the poorer countries, as suggested in our earlier work. In these experiments, we are limited to the group of 19 OECD countries we studied in earlier papers, since that is the sample for which we have comparable data for employment and stocks of physical capital. The first equation repeats the OECD equation of Table 3, using the Mankiw et al data, but with 19 instead of 22 countries. The smaller sample makes no material difference to the results. The second equation continues with the 19-country sample, but uses the OECD national accounts data instead of the Mankiw et al data. This leads to some increase in the investment effect, and to some reduction in the overall explanatory power of the equation.

The third equation continues to use the OECD national accounts data, but changes the dependent variable from the growth of real GDP per adult to the growth of the Solow residual. If technical progress grows at the same constant rate in each country, then there should be no convergence effect apparent in the Solow residual, and hence the initial productivity level should drop out of the equation. The results show that this does not happen, and that the initial productivity level has a strong negative effect, even though the schooling variable remains in the 
equation to guard against the possibility that ignoring international differences in human capital had been responsible for our earlier finding.

The results also show no effect for investment. This is as one would expect in an equation for Solow residuals, since the effect of capital growth is already built into the dependent variable. However, if there were important capital embodiment effects in the implementation of technical progress, then one might expect to find that countries with higher investment rates had higher productivity growth rates. Similarly, if capital investment had important external effects, through the creation of knowledge spillovers at the national level, then one might also expect to find a positive effect from the investment rate. Neither of these influences appears to be important in this sample of industrial countries. Finally, the insignificance of the schooling variable may suggest that the secondary school enrollment rate is an inadequate measure of the differences in human capital among the industrial countries, where differences in higher education and research may be more important.

\section{CONVERGENCE AND THE REAL EXCHANGE RATE}

We are interested in several key issues. First, is it still true, as pointed out earlier by Kravis and Lipsey (1983), Hill (1986) and Heston and Summers (1988), that there is a significant positive relationship between a country's real exchange rate and its relative GDP? If so, is that relationship one that is maintained in a fairly stable way from one decade to the next? If the relationship is stable, and if convergence of per capita real GDPs is a powerful tendency, then we might expect to find some lessening of the cross-sectional variations of both real per capita incomes and of real exchange rates from decade to decade. 
In assessing the evidence we must distinguish, as Barro and Sala i Martin (1990. 1991) point out, what they call $\beta$ convergence from what they call $\sigma$ convergence. $\beta$ convergence, which in the terminology that we have adopted for this paper should be referred to as $k$ convergence (as defined in equation (3)), relates to the partial convergence effect that we and others have found to be significant, as evidenced by the coefficients on the initial income variable. $\sigma$ convergence relates to what happens to the cross-sectional variation in per capita real incomes as time passes. There are several reasons why significant $\beta$ or $\mathrm{k}$ convergence need not imply $\sigma$ convergence. Barro and Sala $\mathrm{i}$ Martin emphasize the fact that different countries are likely to be subject to different disturbances, and that the variance of these disturbances may not be constant from decade to decade. In addition, since we are interested in the $\sigma$ for real exchange rates as well as for real incomes, there is the question of disturbances to real exchange rates as well as to real incomes.

The correlations in Table 5 show that for the 98-country sample as a whole there have been no noticeable decade-to-decade trends in $\sigma$ for cross-sectional variations of real exchange rates, real GDP per capita or real GDP per adult. Similarly, there has been little apparent trend in the correlation between real exchange rates and real per capita GDPs. Disaggregating by average income, there appears to have been $\sigma$ convergence for real incomes, but not for real exchange rates, within the richer two quartiles. There appears to be $\sigma$ divergence for both real incomes and real exchange rates in the two poorer quartiles. As for the correlation between real exchange rates and real incomes, it is strong among the countries in the richest quartile ${ }^{19}$, and effectively zero in the three other quartiles. This appears to contrast with the

\footnotetext{
${ }^{19}$ Although the 1980s show some apparent lessening of the correlation between real incomes and real exchange rates.
} 
results in Helliwell and Chung (1990b), where we found a consistently strong correlation between real incomes and real exchange rates for the industrial countries and for a group of Asian economies. To reconcile these two results, we turn now to consider the correlations on a regional basis, as reported on a decade-by-decade basis in Table 6 and depicted for 1985 in Figures 9 though 12.

The results in Table 6 show strong correlations between real incomes and real exchange rates for Asia and for the OECD, thus confirming the earlier results, but relatively slight positive correlation in Africa and, for the 1980s, a negative correlation in Latin America. As for the international variability of real incomes, there is some evidence of $\sigma$ convergence for the OECD and for Latin America, while there is $\sigma$ divergence in Asia and Africa.

Figures 9 through 12 show the correlations for 1985 between real exchange rates and real per capita GDPs in Africa, Asia, Latin America and the OECD. As suggested by the correlations reported for the 1980s in Table 6, there is a close positive relationship for Asia and the OECD, a much weaker one for Africa, and a slight negative relation for Latin America. Regressions using per capita real GDP to explain cross-sectional variation in 1985 real exchange rates for the 91 countries in the four regions reveal that the data accept a common relationship applicable to Asia and the OECD countries, but strongly reject its applicability to Latin America and Africa. For Asia and the OECD, the elasticity of the real exchange rate with respect to real per capila GDP is $.475(t=9.6)$; this drops to .146 for Africa and is -.295 for Latin America ${ }^{20}$.

20 The adjusted $R^{2}$ for the 91 -country equation is .531 . The homogeneity of the slope coefficients and constant terms for Asia and the OECD is not rejected $(p=.33)$, while similar restrictions are strongly rejected for Latin America $\left(p=10^{4}\right)$ and for Africa $\left(p<10^{4}\right)$. 
There is not space in this paper to dig much deeper into the reasons for these discrepancies, but it seems likely that the relationship between real GDP and the real exchange rate is tighter for more open economies and weaker where national inflation rates are higher and uncertain.

\section{CONCLUSIONS}

What are the main features of our results? The evidence from all countries suggests that production structures ought to be modelled, especially for the developing countries, in a way that takes account of the accumulation of human as well as physical capital ${ }^{21}$. The evidence from the industrial countries, where there are fairly comparable measures of capital stocks, and hence of Solow residuals, also suggests that there is evidence of international convergence in the rates of technical progress. These results suggest, if they are subsequently supported for the developing countries when better data become available relating to capital stocks, that prospects for growth of real per capita incomes in the poorer countries are thus brighter than they otherwise would have been. Earlier research for the industrial countries ${ }^{22}$ also suggests that growth of Solow residuals has also been higher for countries that have had faster relative increases in their foreign trade ${ }^{23}$. Since we have found significant differences in growth patterns and experiences among the developing countries, this result linking trade growth

${ }^{21}$ De Long and Summers (1991) suggest that it may be important to separate the various types of investment, since they find equipment investment to have a much higher effect on growth than does other forms of fixed investment. They also note the importance of allowing for differences in the relative prices of investment goods. See also the results in Helliwell and Chung (1990a) comparing business, private and total capital.

${ }^{22}$ As reported in Helliwell and Chung (1990a).

${ }^{23}$ Similar possibilities for productivity-enhancing trade growth are also noted by Rivera-Batiz and Romer (1991a, 1991b). 
and productivity growth should not be presumed to apply globally unless it is confirmed by evidence for the various groups of developing countries.

The applicability of the convergence model differs substantially by region, with its success being greatest for the OECD and Latin America, rather less for Africa, and non-existent for Asia. Thus it would appear that a fuller explanation for the diversity of Asian growth experiences will require more than the Solow model, even when augmented by human capital, technological convergence and scale effects.

One surprise in our current results is that the linkage between real exchange rates and real per capita incomes, which was found to be strong and sustained for the OECD and a sample of Asian economies, tums out to be of much less importance for Africa and Latin America. This may reflect differences in openness to trade, the prevalence of capital controls and restricted exchange rate regimes in Africa and Latin America, or some other factors. It may also be significant that average growth rates in Africa and Latin America have been below those in other regions, even after allowing for different rates of investment in human and physical capital. This may suggest that international involvements of the sort that lead to tighter linkages between real incomes and real exchange rates may also lead to higher average growth rates. For example, Gylfason (1990), Fischer (1991) and others have shown a linkage between higher inflation rates and lower growth. Macroeconomic policies that lead to higher and/or more variable inflation rates apparently are associated with lower average growth rates, even after allowing for differences in initial incomes and differing rates of investment in physical and 
human capital ${ }^{24}$. These same types of macroeconomic policy that apparently have negative effects on growth may also be responsible for the looser linkage between per capita GDP and the real exchange rate. More research is clearly required to spell out the reasons for the lesser real exchange rate linkages, as well as for the lower growth rates, in both Africa and Latin Anerica.

For the modelling of longer-term real exchange rates, it might therefore be suitable to make use of the relationship between real incomes and real exchange rates for the industrial and Asian economies, but not yet for Latin America and Africa. Even for the OECD and Asian economies, the net predictive contribution of convergence and the real income linkage for the modelling of subsequent exchange rate movements remains to be analyzed.

\section{REFERENCES}

Abramovitz, M. (1979) "Rapid Growth Potential and its Realization: The Experience of Capitalist Economies in the Postwar Period." In E. Malinvaud, ed., Economic Growth and Resources (London: Macmillan) 1-30.

Abramovitz, M. (1990) "The Catch-up Factor in Postwar Economic Growth." Economic Inquiry: 1-18.

Alesina, A. and D. Rodrik (1991) "Distributive Politics and Economic Growth." CEPR Discussion Paper No. 565 (London: Centre for Economic Policy Research).

Backus, D.K., P.J. Kehoe and T.J. Kehoe (1991) "In Search of Scale Effects in Trade and Growth." Working Paper No. 451 
Barro, R.J. (1991) "Economic Growth in a Cross Section of Countries." Quarterly Journal of Economics 106:407-44.

Barto, R.J. and X. Sala i Martin (1990) "Economic Growth and Convergence Across the United States." NBER Working Paper No. 3419 (Cambridge: National Bureau of Economic Research).

Baumol, W.J. (1986) "Productivity Growth, Convergence and Welfare: What the Long-Run Data Show." American Economic Review 76: 1072-85.

Baumol, W.J., S. Blackman and E.N. Wolff (1989) Productivity and American Leadership, The Long View. (Cambridge Mass., MIT Press).

Baumol, W.J., and E.N. Wolff (1988) "Productivity Growth, Convergence and Welfare: Reply." American Economic Review 78: 1155-59.

Bernard, A.B. and S.N. Durlauf (1991) "Convergence of International Output Movements." NBER Working Paper No. 3717 (Cambridge: National Bureau of Economic Research).

Brander, J.A. and S. Dowrick (1991) "The Role of Fertility and Population in Economic Growth: New Results From Aggregate Cross-National Data." (mimeo.)

Blades, D. and D. Roberts (1987) "A Note on the New OECD Benchmark Purchasing Power Parities for 1985." OECD Economic Studies 9: 153-84.

Chenery, H., S. Robinson and M. Syrquin (1986) Industrialization and Growth: A Comparative Study. (Washington: The World Bank).

Currie, D. and D. Vines, eds., (1988) Macroeconomic Interactions Between North and South (Cambridge: Cambridge University Press).

Dasgupta, P. (1991) "Nutrition, Non-Convexities and Redistributive Policies." Economic Journal 101: 22-6.

De Long, J.B. (1988) "Productivity Growth, Convergence and Welfare: Comment." American Economic Review 78: 1138-54.

De Long, J.B. and L.H. Sumıers (1991) "Equipment Investment and Economic Growth." Quarterly Journal of Economics 106:445-502.

Dowrick, S. and D-T. Nguyen (1989) "OECD Comparative Economic Growth 1950-85: Catch-Up and Convergence." American Economic Review 79: 1010-30. 
Dowrick, S. and N. Gemmell (1991) "Industrialisation, Catching Up and Economic Growth: A Comparative Study Across the World's Capitalist Economies." Economic Journal 101:26.3-275.

Eswaran, M. and A. Kotwal (1989) "Can Trade with North Make South Poorer?" (University of $\mathrm{BC}$, mimeo.)

Fischer, S. (1991) "Growth, Macroeconomics, and Development." NBER Working Paper No. 3702 (Cambridge: National Bureau of Economic Research).

Grossman, G.M. and E. Helpman (1989) "Quality Ladders and Product Cycles." NBER Working Paper No. 3201 (Cambridge: National Bureau of Economic Research).

Grossman, G.M. and E. Helpman (1990a) "Trade, Innovation, and Growth." American Economic Review 80 (2): 86-91.

Grossman, G.M. and E. Helpman (1990b) "Comparative Advantage and Long-Run Growth." American Economic Review 80:796-815.

Gylfason, T. (1990) "Inflation, Growth and External Debt: A Review of the Landscape." CEPR Discussion Paper No. 375. (London: Centre for Economic Policy Research).

Hansson, A., and J. Helliwell (1990) "The Evolution of Income and Competitiveness in the North Pacific Rim." In F. Langdon, ed. Canada and the Growing Presence of Asia. (Vancouver: Institute for Asian Research) 17-40.

Helliwell, John F. (1991) "Are Nations Growing Together or Falling Apart?" (Mabel F. Timlin Lecture, University of Saskatchewan, Saskatoon, April 8, 1991)

Helliwell, John F., and Alan Chung (1986) "Aggregate Output with Variable Rates of Utilization of Employed Factors." Journal of Econometrics 19: 597-625.

Helliwell, John F., and Alan Chung (1988) "Aggregate Productivity and Growth in an International Comparative Setting." Prepared for SSRC conference, Stanford University, October 1988. Forthcoming in B.G. Hickman, ed., International Productivity and Competitiveness (New York: Oxford University Press).

Helliwell, John F., and Alan Chung (1990a) "Macroeconomic Convergence: International Transmission of Growth and Technical Progress." NBER Working Paper No. 3264 (Cambridge: National Bureau of Economic Research).

Helliwell, John F. and Alan Chung (1990b) "Tri-polar Growth and Real Exchange Rates: How Much Can be Explained by Convergence?" (Prepared for the Symposium on A Quest for a More Stable World Economic System, Osaka, October 23-25, 1990) 
Helliwell, John F. and Alan Chung (1991a) "Globalization, Convergence, and the Prospects for Economic Growth." In J. Cornwall, ed. The Capitalist Economies: Prospects for the 1990s (London: Elgar).

Helliwell, John F. and Alan Chung (1991b) "Are Bigger Countries Better Off?" (Prepared for the Roundtable on "Economic Dimensions of Constitutional Change", John Deutsch Institute, Queen's University, June 4-6, 1991.)

Helliwell, John F., Peter Sturm, Gerard Salou (1985) "International Comparison of the Sources of the Productivity Slowdown 1973-1982." European Economic Review 28: 157-91.

Helpman, E. (1991) "Endogenous Macroeconomic Growth Theory." NBER Working Paper No. 3869 (Cambridge: National Bureau of Economic Research).

Heston, A. and R. Summers (1988) "What Have We Learned About Prices and Quantities From International Comparisons: 1987." American Economic Review 78 (2): 467-73.

Hill, P. (1986) "International Price Levels and Purchasing Power Parities." OECD Economic Studies 6: $133-59$.

Kravis, I.B. and R.E. Lipsey (1983) Toward an Explanation of National Price Levels. Princeton Studies in International Finance No 52. (Princeton: International Finance Section).

Kreuger, A.O. (1968) "Factor Endowments and Per Capita Income Differences Among Countries." Economic Journal 78: 641-59.

Landes, D. (1990) "Why Are We So Rich and They So Poor?" American Economic Review $80(2): 1-13$.

Lucas, R.E. (1988) "On the Mechanics of Economic Development." Journal of Monetary Economic 22: 3-32.

Lucas R.E. (1990) "Why Doesn't Capital Flow from Rich to Poor Countries?" American Economic Review 90 (2): 92-96.

Maddison, A. (1982) Phases of Capitalist Development. (Oxford: Oxford University Press).

Mankiw, G., D. Romer and D. Weil (1990) "A Contribution to the Empirics of Economic Growth." NBER Working Paper No. 354l. (Cambridge: National Bureau of Economic Research).

Rauch, J.E. (1989) "The Question of International Convergence of Per Capita Consumption: An Euler Equation Approach." NBER Summer Institute Paper. (Cambridge: National Bureau of Economic Research). 
Rivera-Batiz, L.A. and P. Romer (1991a) "Economic Integration and Endogenous Growth." Quarterly Journal of Economics 106:531-56. Also NBER Working Paper No. 3528 (Cambridge: National Bureau of Economic Research).

Rivera-Batiz, L.A. and P. Romer (1991b) "International Trade with Endogenous Technical Change. " NBER Working Paper No. 3594 (Cambridge: National Bureau of Economic Research).

Romer, P.M. (1986) "Increasing Returns and Long-Run Growth." Journal of Political Economy 94: 1002-37.

Romer, P.M. (1989) "Human Capital and Growth: Theory and Evidence." NBER Working Paper No. 3173 (Cambridge: National Bureau of Economic Research).

Romer, P.M. (1990a) "Are Non-Convexities Important for Understanding Growth?" American Economic Review 80 (2): 97-103.

Romer, P.M. (1990b) "Endogenous Technological Change." Journal of Political Economy 98: S71-S102.

Rostow, W.W. (1978) The World Economy: History and Prospect. (Austin: University of Texas).

Solow, R.M. (1956) "A Contribution to the Theory of Economic Growth." Quarterly Journal of Economics 70: 65-94.

Solow, R.M. (1957) "Technical Change and the Aggregate Production Function." Review of Economics and Statistics 39: 312-20.

Stern, N. (1991) "The Determinants of Growth." The Economic Journal 101: 122-33.

Summers, R. and A. Heston (1988) "A New Set of International Comparisons of Real Product and Prices: Estimates for 130 Countries, 1950 to 1985." Review of Income and Wealth 34: 1-25. 
</ref_section> 
Table 1

Convergence Tests using 98-Country Sample

\begin{tabular}{|c|c|c|c|c|}
\hline No. of Observations & 98 & 98 & 98 & 98 \\
\hline Degrees of Freedom & 93 & 92 & 94 & 93 \\
\hline Constant & $\begin{array}{l}3.030 \\
(.827)\end{array}$ & $\begin{array}{l}2.498 \\
(.826)\end{array}$ & $\begin{array}{l}2.454 \\
(.473)\end{array}$ & $\begin{array}{l}1.758 \\
(.536)\end{array}$ \\
\hline Coefficients: & & & & \\
\hline scale & & $\begin{array}{c}.065 \\
(.024)\end{array}$ & & $\begin{array}{r}.0621 \\
(.024)\end{array}$ \\
\hline cu & $\begin{array}{l}-.288 \\
(.061)\end{array}$ & $\begin{array}{l}-.333 \\
(.062)\end{array}$ & $\begin{array}{l}-.298 \\
(.060)\end{array}$ & $\begin{array}{l}-.343 \\
(.061)\end{array}$ \\
\hline invest & $\begin{array}{l}.526 \\
(.087)\end{array}$ & $\begin{array}{l}.533 \\
(.084)\end{array}$ & & \\
\hline school & $\begin{array}{c}.231 \\
(.059)\end{array}$ & $\begin{array}{c}.189 \\
(.060)\end{array}$ & & \\
\hline$n+g+d$ & $\begin{array}{l}-.503 \\
(.288)\end{array}$ & $\begin{array}{l}-.379 \\
(.283)\end{array}$ & & \\
\hline $\begin{array}{l}\text { invest } \\
-(n+g+d)\end{array}$ & & & $\begin{array}{c}.502 \\
(.082)\end{array}$ & $\begin{array}{c}.501 \\
(.080)\end{array}$ \\
\hline $\begin{array}{l}\text { school } \\
-(n+g+d)\end{array}$ & & & $\begin{array}{c}.235 \\
(.059)\end{array}$ & $\begin{array}{c}.196 \\
(.059)\end{array}$ \\
\hline$\overline{\mathbf{R}}^{2}$ & .464 & .497 & .466 & .495 \\
\hline S.E.E. & .326 & .316 & .326 & .317 \\
\hline
\end{tabular}

Nole: Standard errors are in parenthescs. 


\section{Table 2}

Tests of Convergence for Rich and Poor Countries

For these equations the 98 observations are ranked by average GDP per adult 1960-1985, and divided into quartiles. Scale is measured by average total GDP 1960-1985.

\begin{tabular}{|c|c|c|c|c|}
\hline Quartile samples: & 1st $(1-24)$ & 2 ad $(25-48)$ & $3 r d(49-72)$ & 4th $(73-98)$ \\
\hline No. of Observations & 24 & 24 & 24 & 26 \\
\hline Degrees of Freedom & 18 & 18 & 18 & 20 \\
\hline Constant & $\begin{array}{l}7.382 \\
(1.289)\end{array}$ & $\begin{array}{l}5.830 \\
(1.256)\end{array}$ & $\begin{array}{l}12.05 \\
(3.522)\end{array}$ & $\begin{array}{l}3.869 \\
(2.236)\end{array}$ \\
\hline \multicolumn{5}{|l|}{ Coefficients: } \\
\hline scale & $\begin{array}{c}.037 \\
(.031)\end{array}$ & $\begin{array}{c}.084 \\
(.037)\end{array}$ & $\begin{array}{c}.056 \\
(.047)\end{array}$ & $\begin{array}{c}.090 \\
(.050)\end{array}$ \\
\hline cu & $\begin{array}{l}-.817 \\
(.111)\end{array}$ & $\begin{array}{l}-.846 \\
(.107)\end{array}$ & $\begin{array}{r}-1.069 \\
(.252)\end{array}$ & $\begin{array}{l}-.772 \\
(.162)\end{array}$ \\
\hline invest & $\begin{array}{c}.564 \\
(.198)\end{array}$ & $\begin{array}{c}.222 \\
(.156)\end{array}$ & $\begin{array}{c}.170 \\
(.164)\end{array}$ & $\begin{array}{c}.338 \\
(.108)\end{array}$ \\
\hline school & $\begin{array}{c}.013 \\
(.212)\end{array}$ & $\begin{array}{c}.071 \\
(.117)\end{array}$ & $\begin{array}{c}.310 \\
(.120)\end{array}$ & $\begin{array}{c}.022 \\
(.077)\end{array}$ \\
\hline$n+g+d$ & $\begin{array}{l}-.233 \\
(.348)\end{array}$ & $\begin{array}{l}-.226 \\
(.323)\end{array}$ & $\begin{array}{c}.643 \\
(.830)\end{array}$ & $\begin{array}{l}-.330 \\
(.621)\end{array}$ \\
\hline $\bar{R}^{2}$ & .776 & .758 & .581 & .558 \\
\hline S.E.E. & .203 & .183 & .278 & .230 \\
\hline
\end{tabular}

Nole: Standard errors are in parentheses. 
Table 3

Tests of Convergence by Region

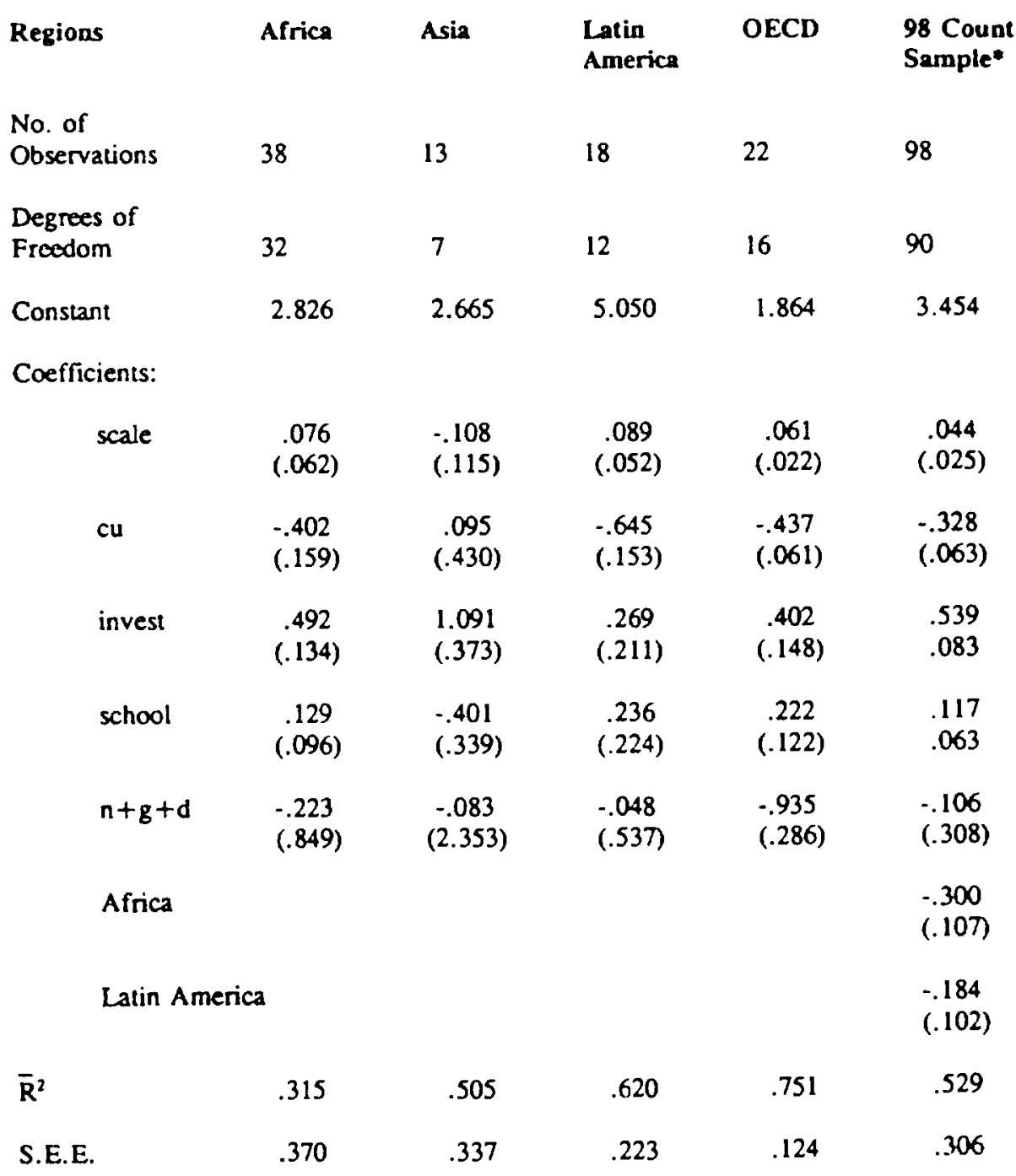

Note: Standard errors are in parentheses.

* With regional dummies for Africa and Latin America (Remainder includes OECD, Asia and residue) 
Table 4

Comparison of Convergence Results for the OECD

Using GDP per Adult and Solow Residuals, 1960-1985

$\begin{array}{lll}\text { GDP per adult } & \text { GDP per adult } & \text { Solow Residuals } \\ \text { M/R/W data } & \text { OECD SNA data } & \text { using OECD SNA data }\end{array}$

\begin{tabular}{|c|c|c|c|}
\hline No. of Observations & 19 & 19 & 19 \\
\hline Degrees of Freedom & 13 & 13 & 13 \\
\hline Constant & 3.246 & 1.606 & 26.620 \\
\hline \multicolumn{4}{|l|}{ Coefficients: } \\
\hline scale & $\begin{array}{c}.054 \\
(.023)\end{array}$ & $\begin{array}{l}.061 \\
(.023)\end{array}$ & $\begin{array}{c}.069 \\
(.024)\end{array}$ \\
\hline $\mathrm{cu}$ & $\begin{array}{r}-.527 \\
(.932\end{array}$ & $\begin{array}{l}-.426 \\
(.106)\end{array}$ & $\begin{array}{l}-.757 \\
(.107)\end{array}$ \\
\hline invest & $\begin{array}{c}.361 \\
(.162)\end{array}$ & $\begin{array}{c}.594 \\
(.251)\end{array}$ & $\begin{array}{l}-.005 \\
(.255)\end{array}$ \\
\hline school & $\begin{array}{c}.119 \\
(.154)\end{array}$ & $\begin{array}{l}.121 \\
(.154)\end{array}$ & $\begin{array}{l}-.110 \\
(.161)\end{array}$ \\
\hline$n+g+d$ & $\begin{array}{l}-.665 \\
(.406)\end{array}$ & $\begin{array}{l}-.253 \\
(.392)\end{array}$ & $\begin{array}{c}.456 \\
(.440)\end{array}$ \\
\hline $\mathrm{R}^{2}$ & .797 & .702 & .845 \\
\hline S.E.E. & .129 & .123 & .128 \\
\hline
\end{tabular}

Notes: Standard errors are in parentheses.

The Mankiw/Romer/Weil data are mainly from the Penn World Table (Mark 4) (Heston and Summers 1988). GDP is measured in 1980 intemational dollars. The OECD SNA data are from the 1990 OECD National Accounts database. Purchasing power parities for 1985 are used to convert the GDP data into 1985 international dollars. The appendix contains more information on the data and the derivation of the Solow residual. For regressions (1) and (2), the dependent variable is defined as the log difference in GDP per adult over the period 1960-85, and $\mathrm{Cu}$ is the logarithm of $1960 \mathrm{gdp}$ per adult. For regression (3) the dependent variable is defined as the change in the logarithm of the Solow residual, and $\mathrm{Cu}$ is the 1960 logarithm of the Solow residual. The sample used in the above regressions contains the following 19 countrics: USA, Japan, Canada, France, Germany, Italy, United Kingdom, Australia, Austria, Belgium, Denmark, Finland, Ireland, Netherlands, New Zealand, Norway, Spain, Sweden and Switzerland. 
Table 5

Real Exchnoge Rates and Real GDP per Capita

Ranked by average GDP per adult and divided into quartiles.

Ist qrt. 2nd qrt. 3rd qri. 4th qrt. 98 Country

Real Exchange Rate (log)

Std Dev's:

$60-85$

$\begin{array}{lllll}.165 & .209 & .293 & .263 & .322\end{array}$

60 's

.193

.270

.298

.285

.325

70 's

.191

.220

.326

.276

.350

80 's

.166

.208

.349

.373

.372

Real GDP per Capila (log)

Std Dev's:

60-85

60 s

.255

.359

.313

.262

.387

.270

.325

.290

.295

.345

.271

.258

.352

.288

.299

.323

.253

.222

.280

80 's

Correlations between real exchange rate and Real GDP per Capita

.781

.034

$-.023$

.040

.587

60 's

.662

.021

.019

$-.189$

$-.039$

.183

$-.017$

.058

80's

.524

$-.057$

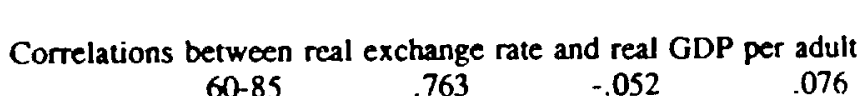

60-85

.763

$-.052$

.085

$-.036$

.697

.033

.015

$-.051$

.548

80 's

$.069 \quad .580$

$-.179$

.498

.205

.577

.069

.560 
Table 6

Real Exchange Rates and Real GDP per Capita

Regional Evidence

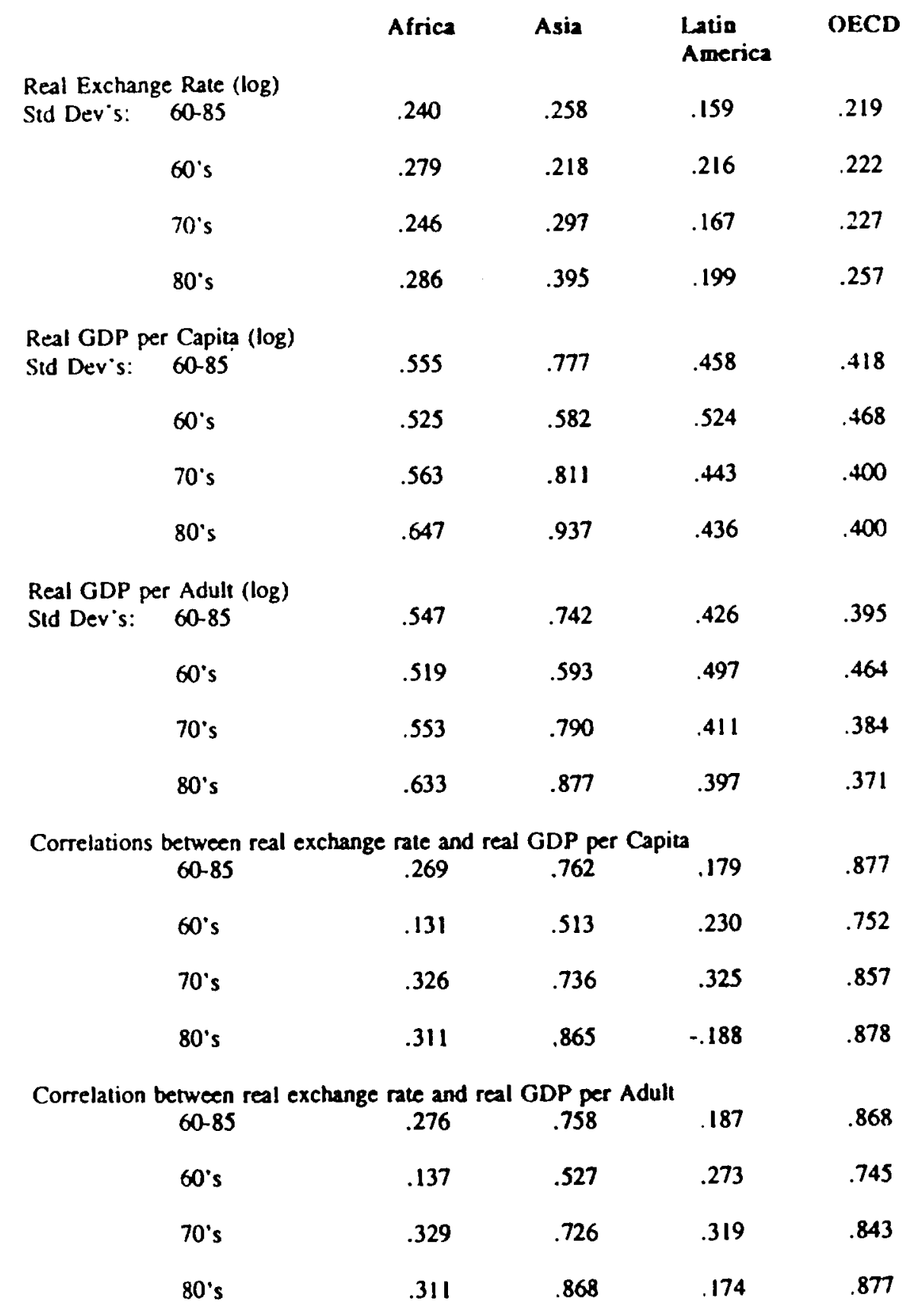


Fig 1: Growth and Initial Income Per

Adult (Quartile 1 rank by aver income)

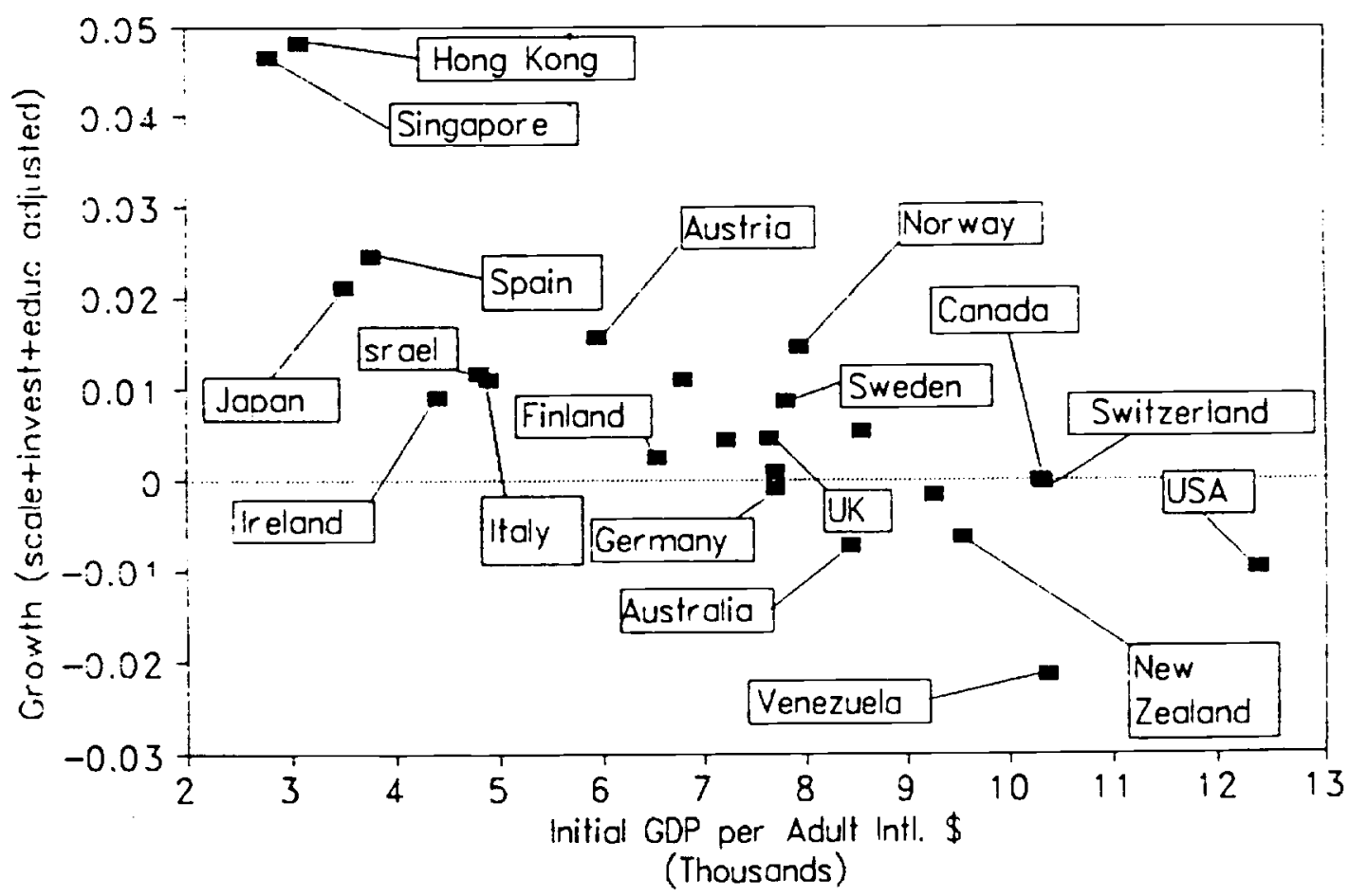


Fig 2: Growth and Initial income Per Adult (Quartile 2 rank by aver income)

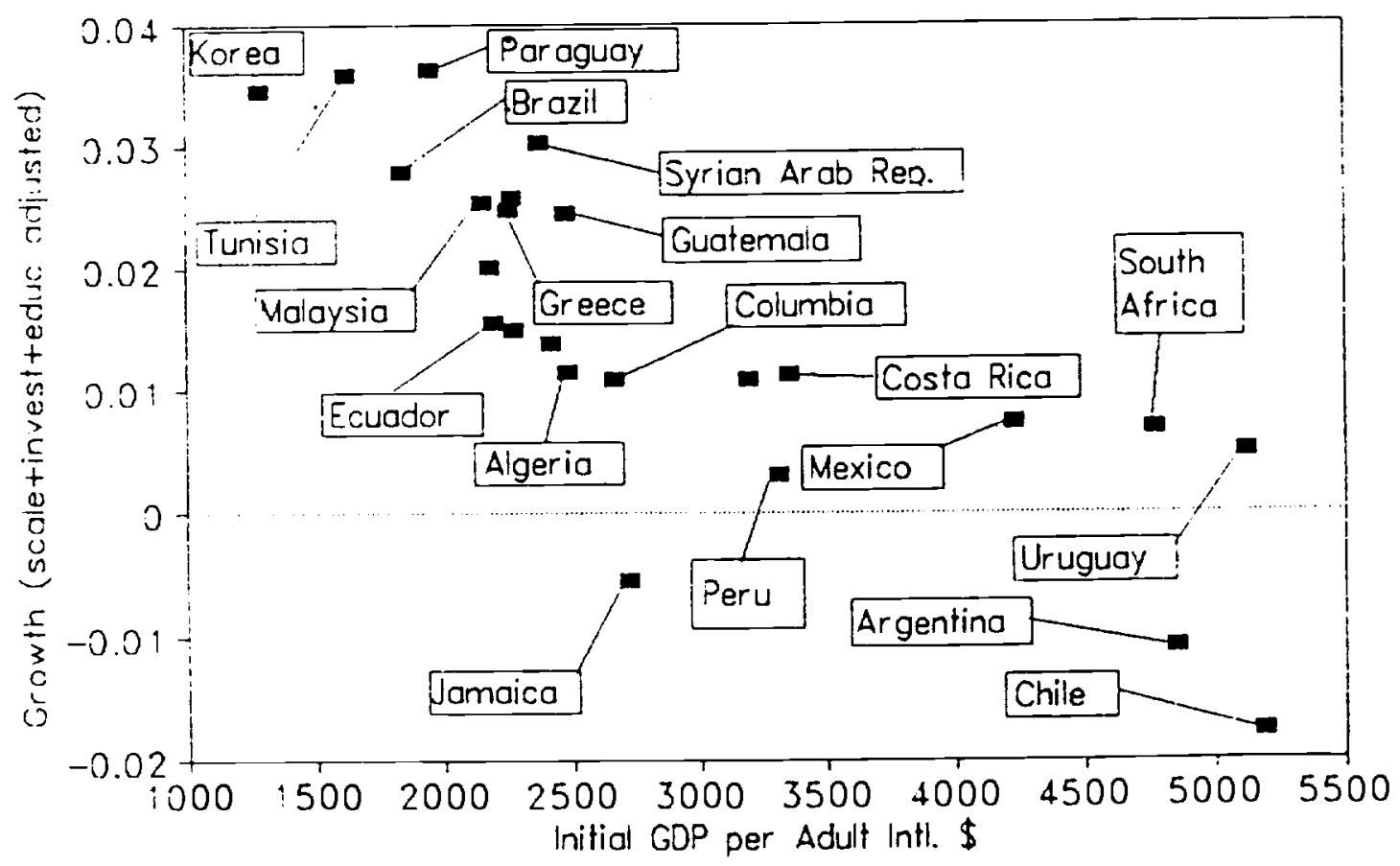


Fig 3: Growtin and initial income Per Adult (Quartile 3 rank by aver income)

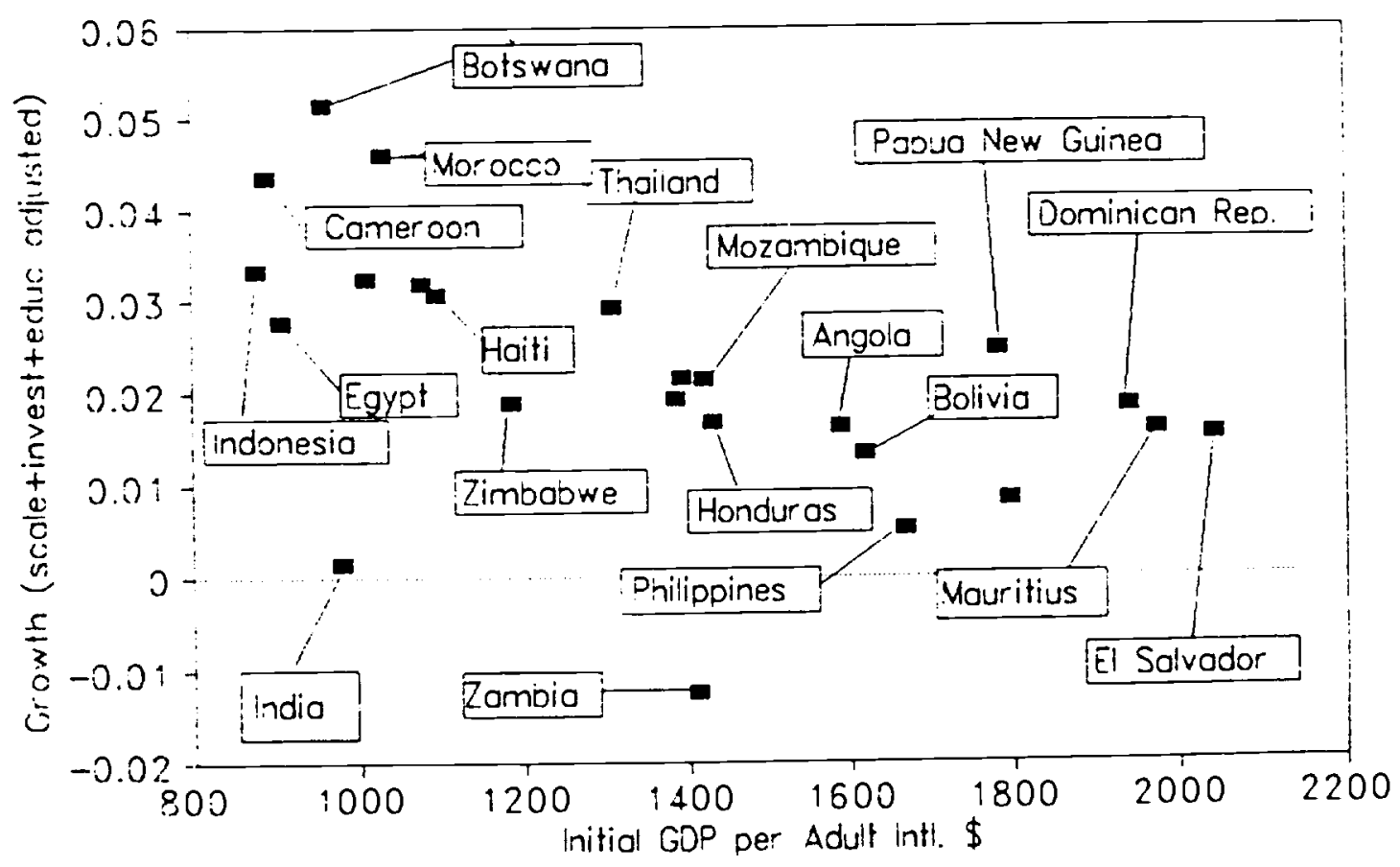


Fig 4: Growth and Initial Income Per

Adult (Quartile 4 rank by aver income)

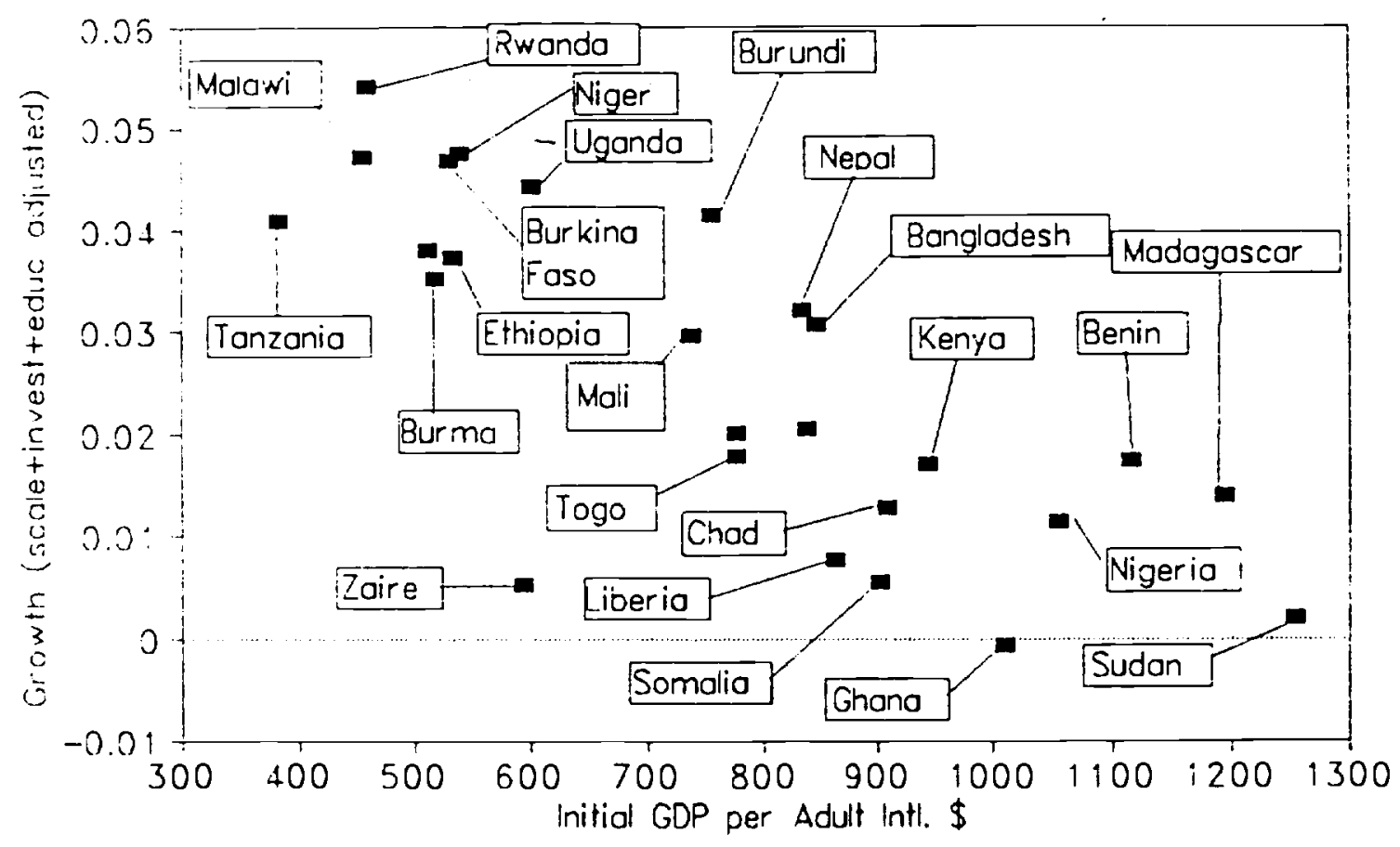


Fig 5: Growth and Initial Income Per Adult: Africa

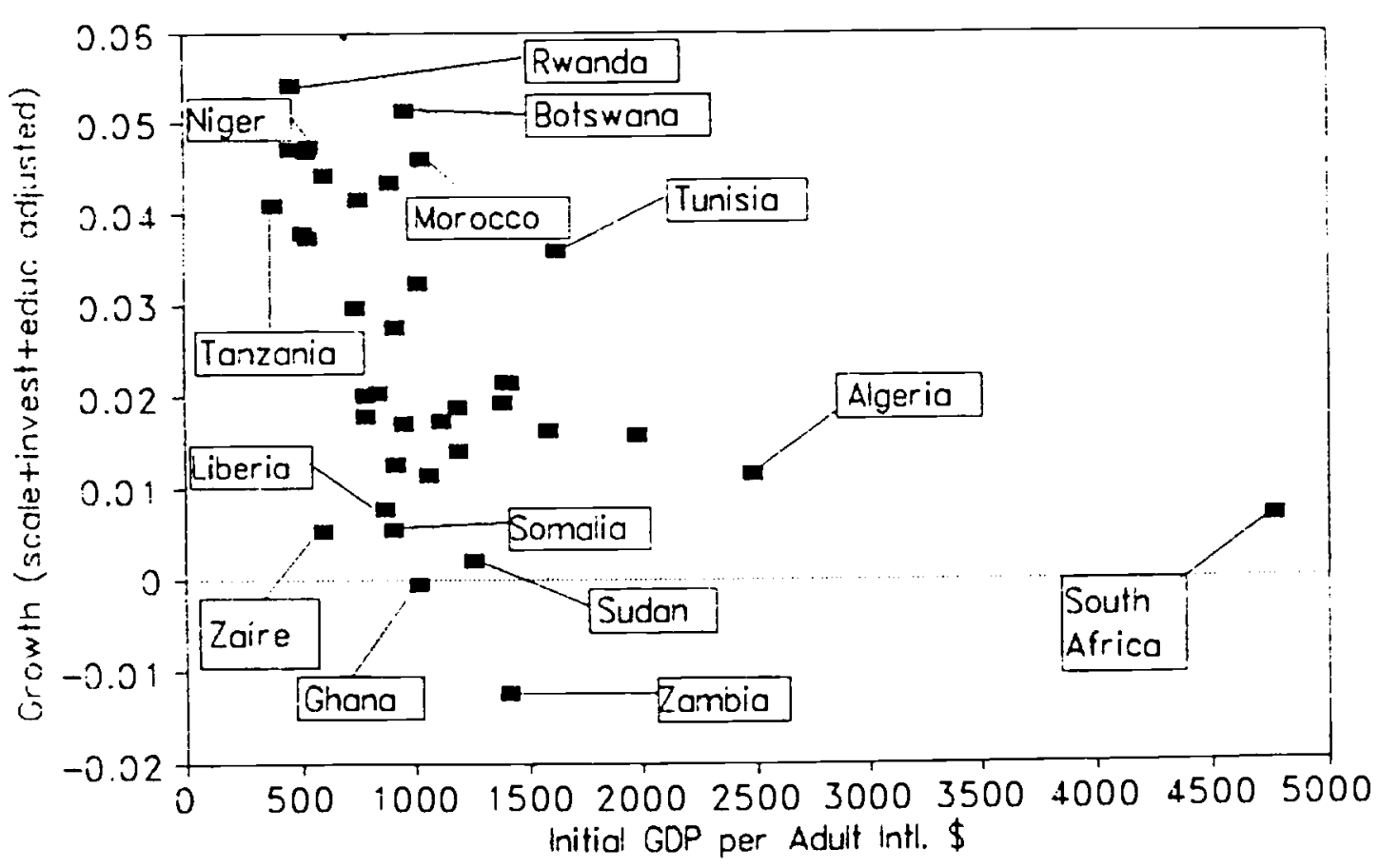


Fig 5: Growth and initiai Income Per Adult: Asia

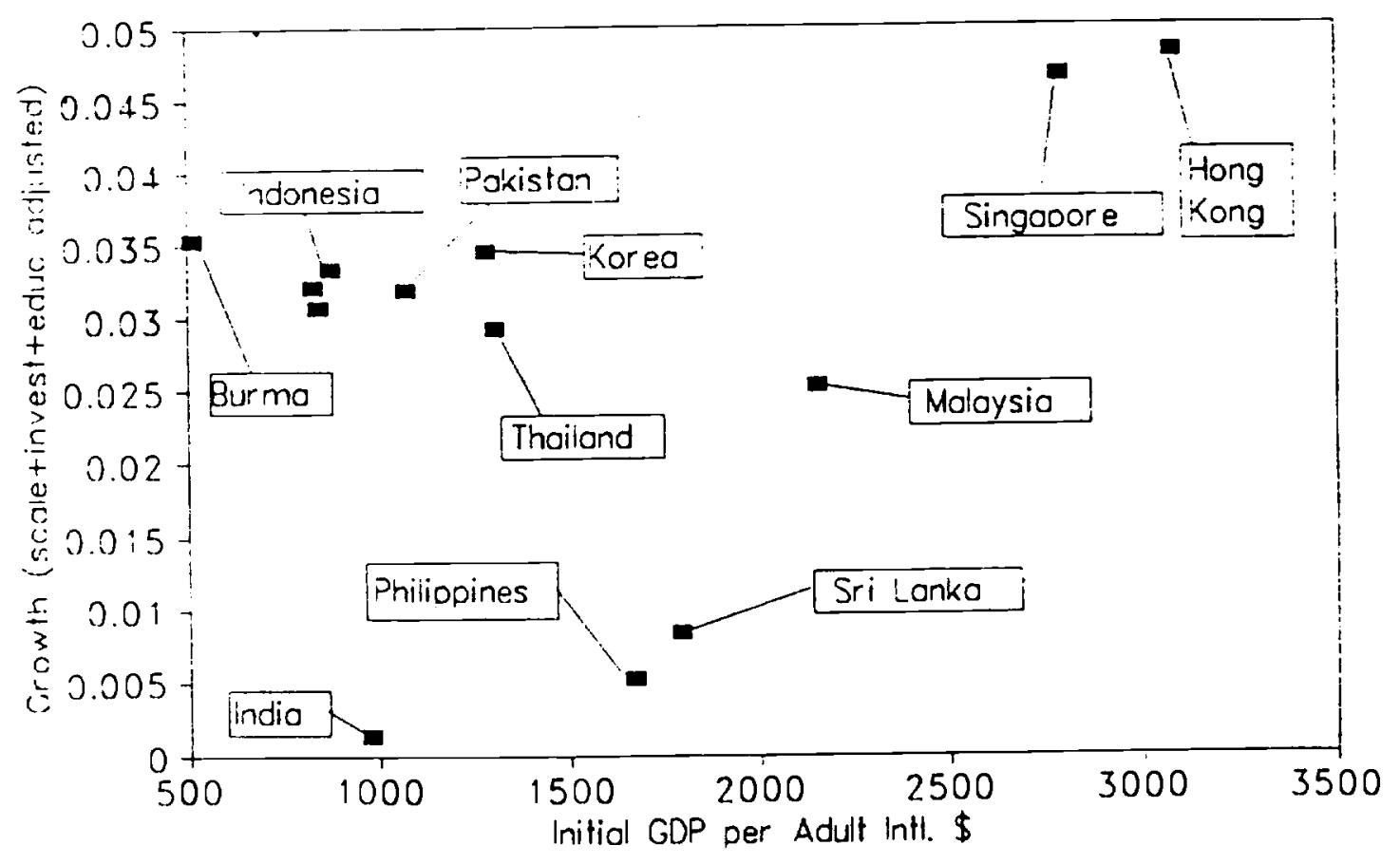


Fig 7: Grawtin and Initial Income Per Adult: Latin America

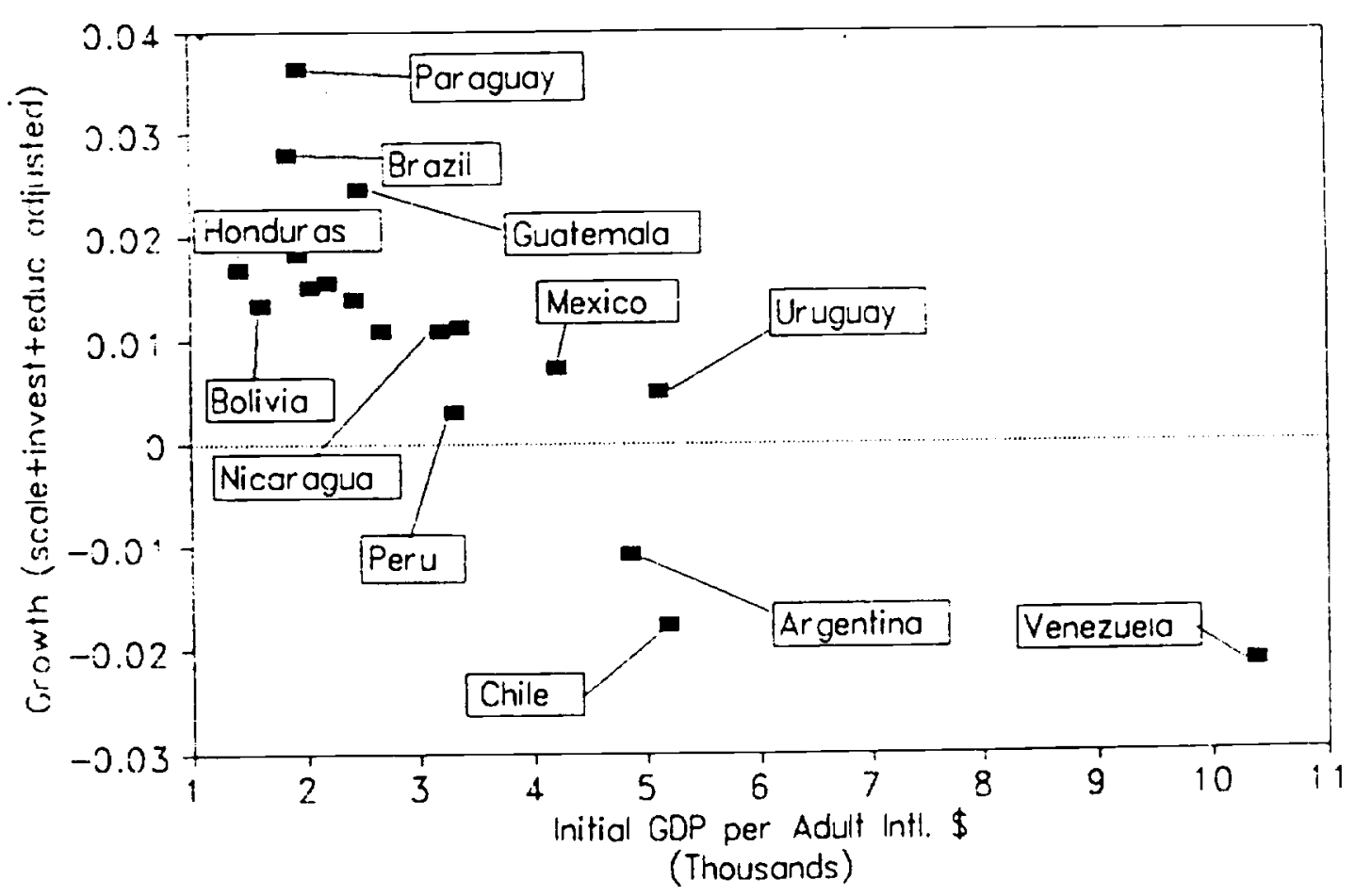


Fig 8: Growth and Initial Income Per Adult: OECD

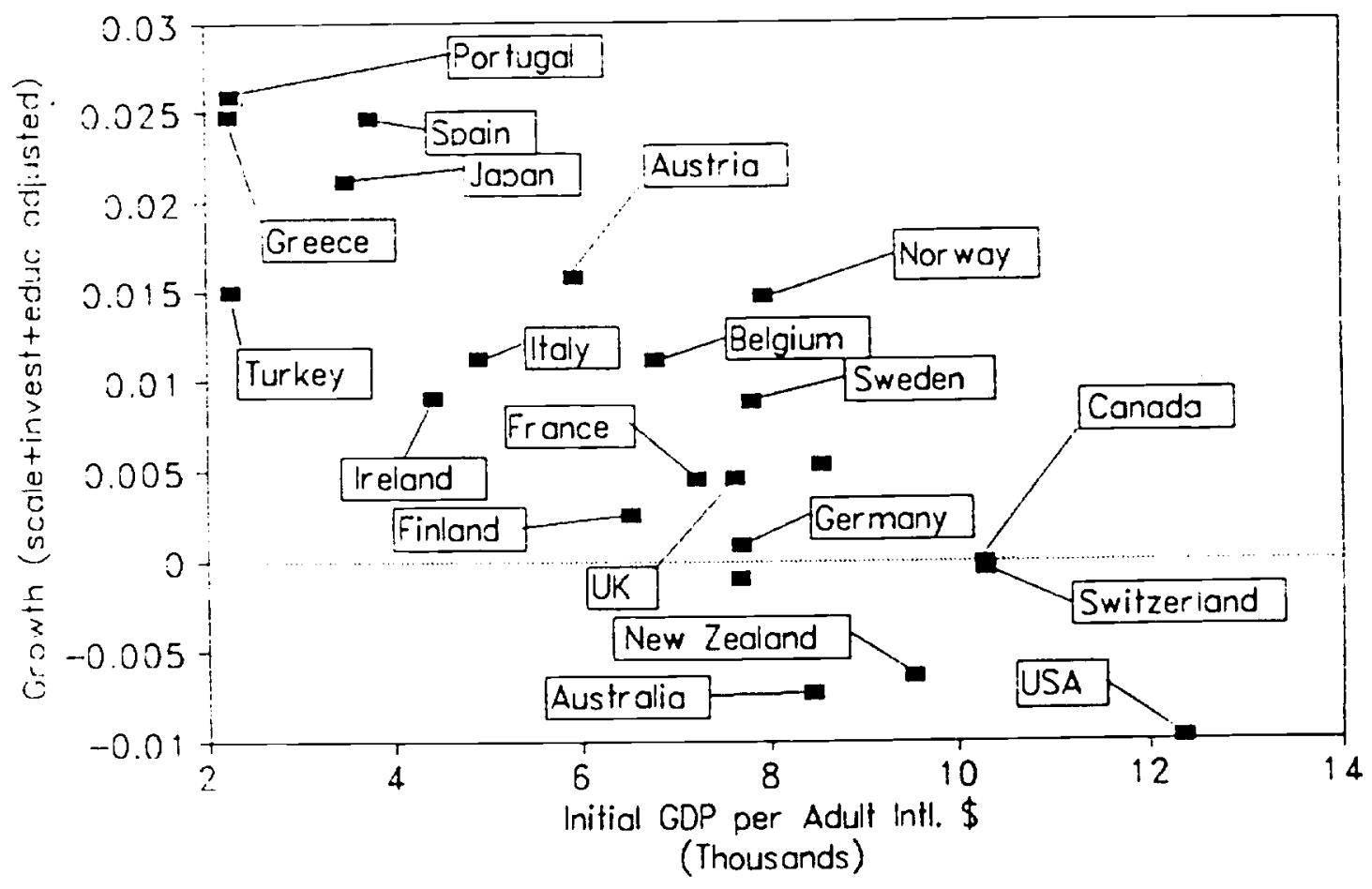


Fig 9: International Price Indices and Real GDP per Capita 1985: Africa

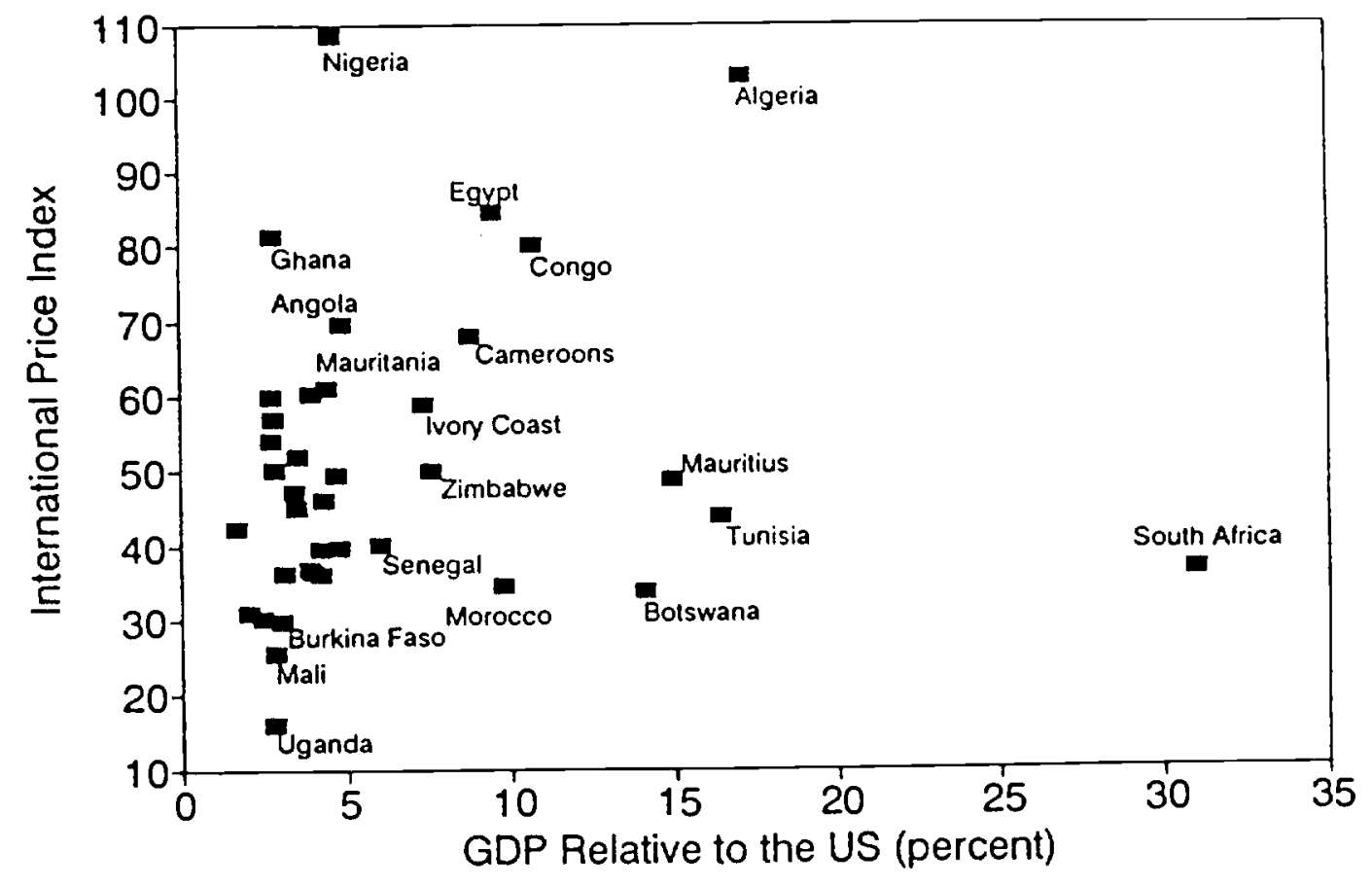


Fig 10: International Price Indices and Real GDP per Capita 1985: Asia

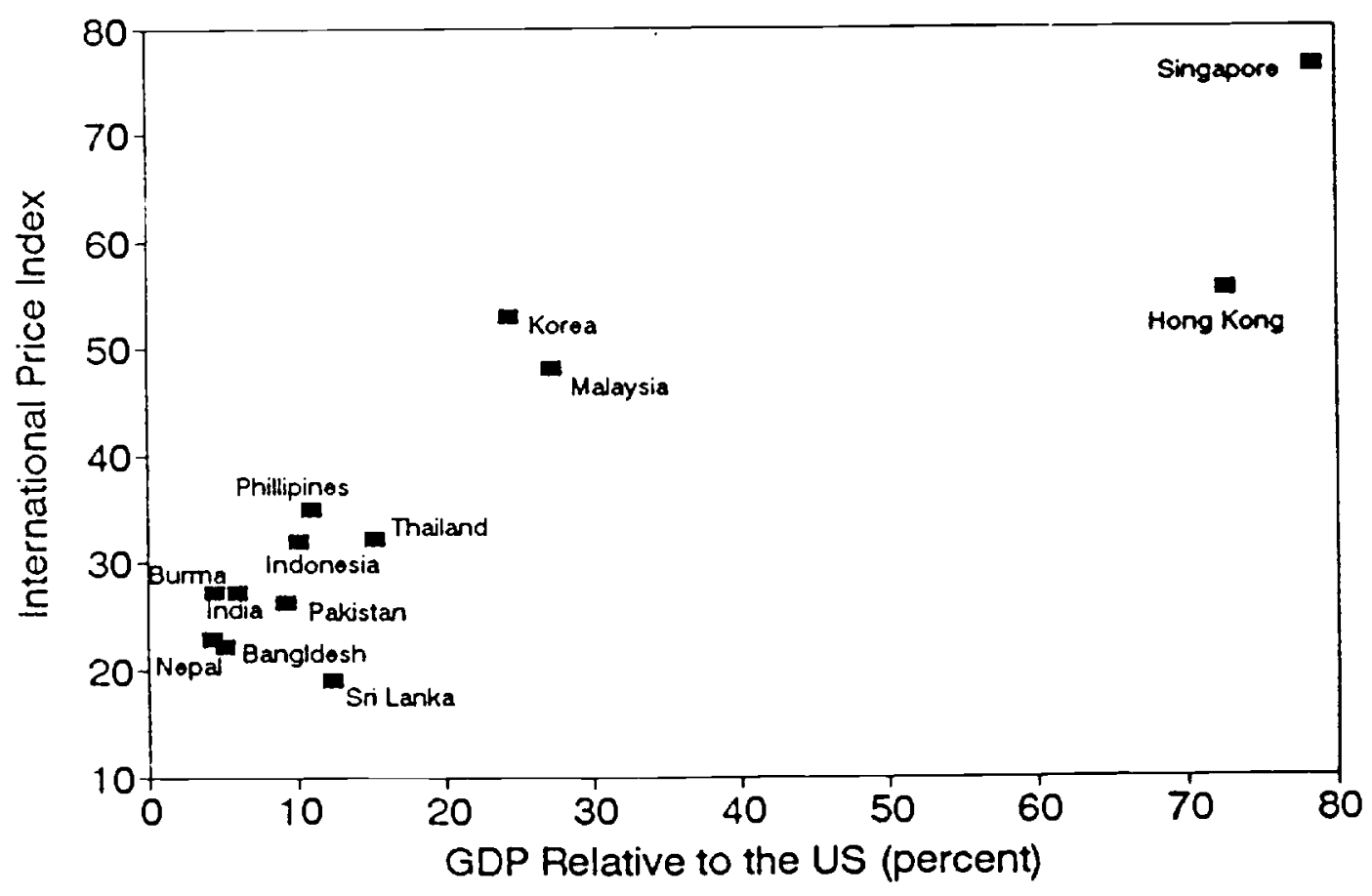


Fig 11: International Price Indices and

Real GDP per Capita 1985: Latin America

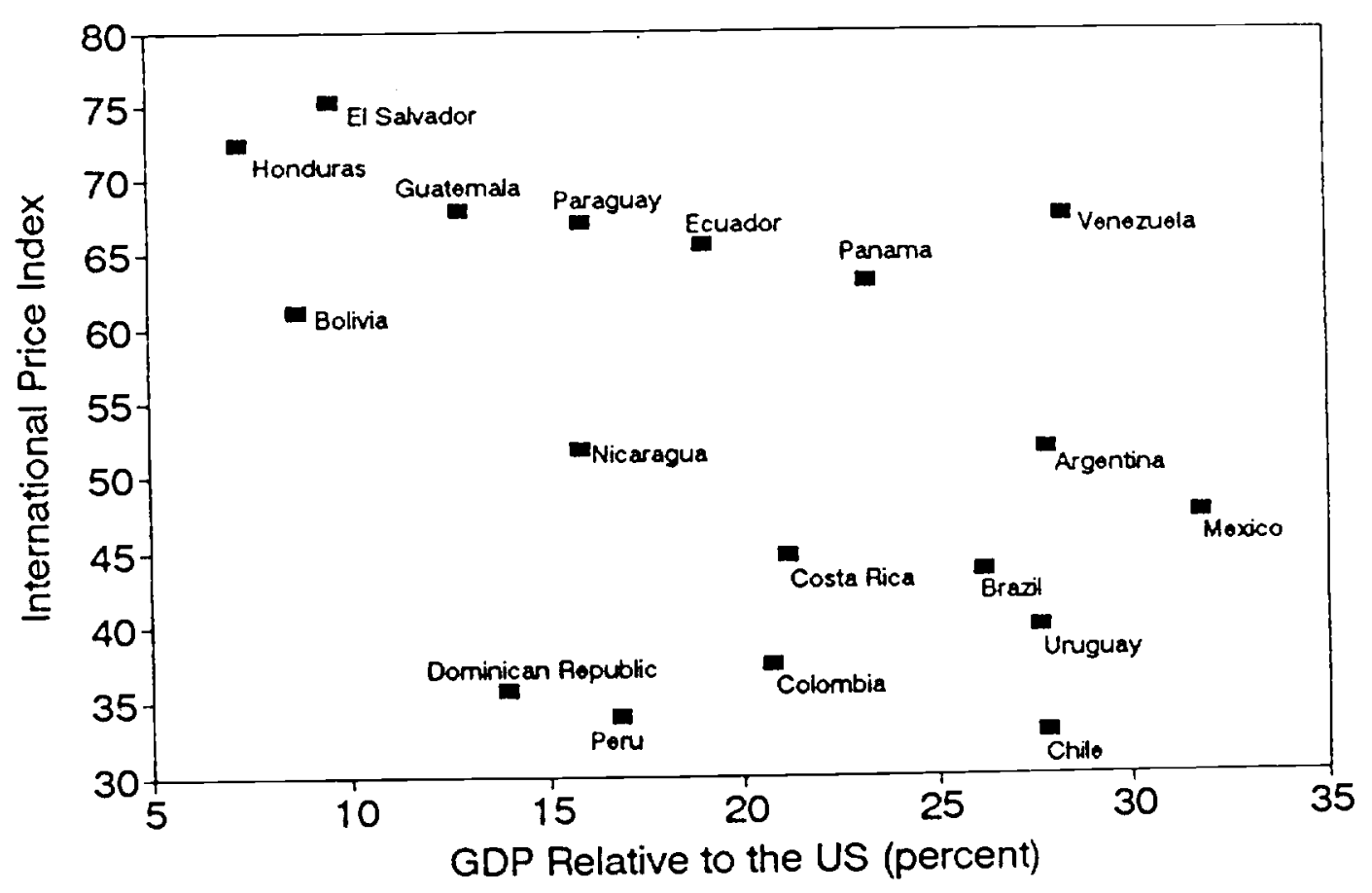


Fig 12: International Price Indices and Real GDP per Capita 1985: OECD

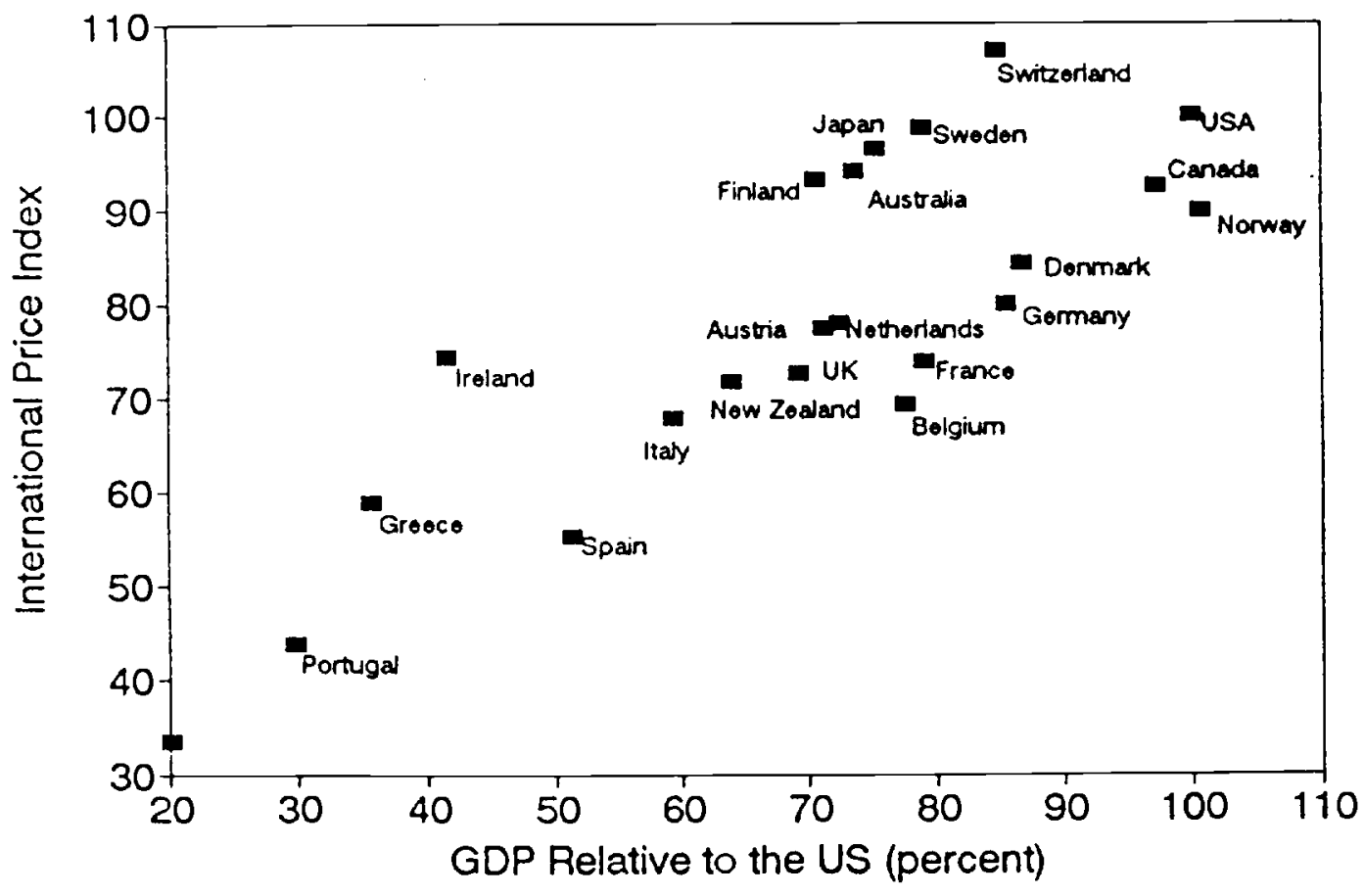




\section{APPENDII}

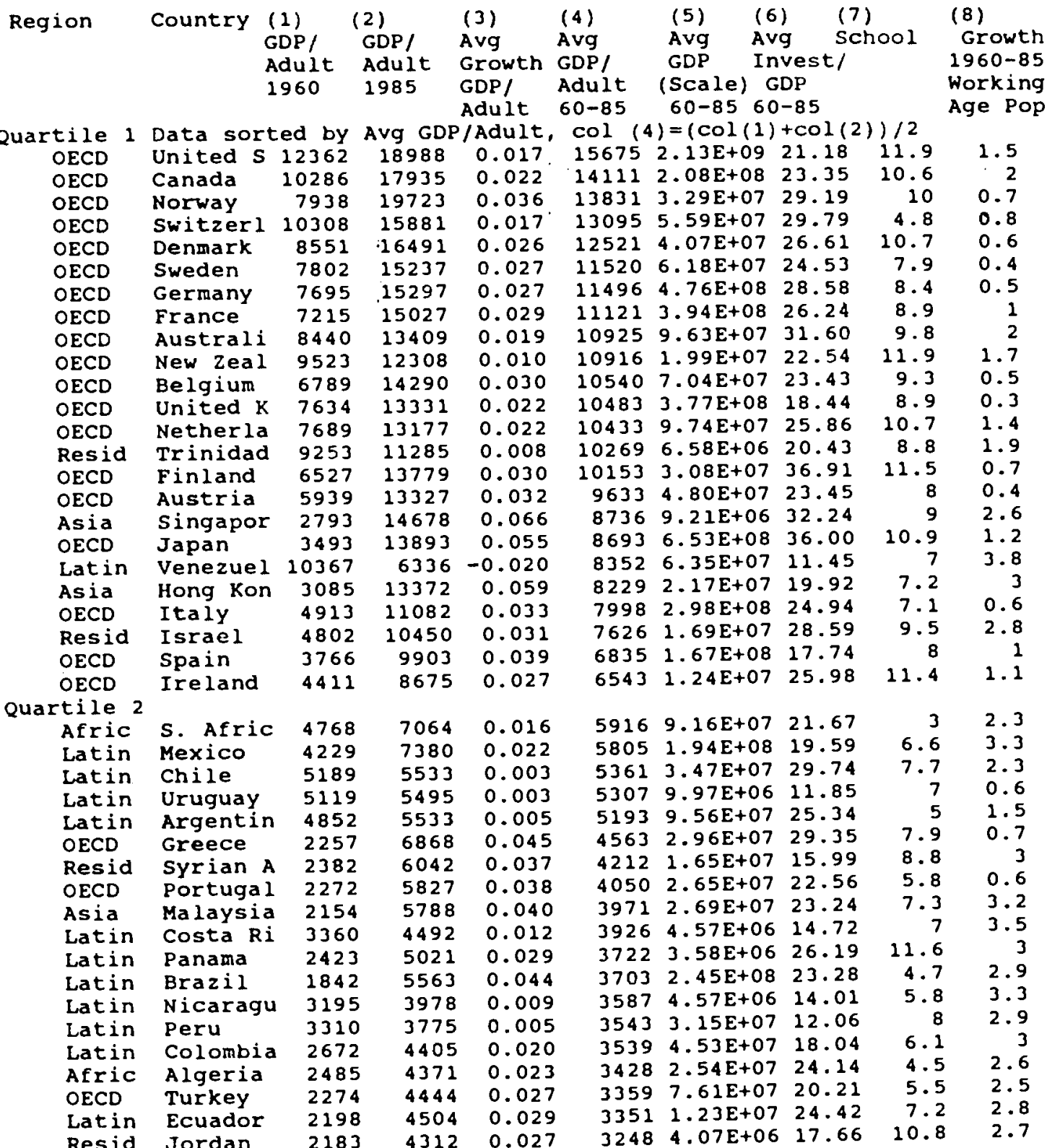




$$
A-2
$$

\begin{tabular}{|c|c|c|c|c|c|c|c|c|c|}
\hline Region & country & $\begin{array}{l}\text { 1) } \\
\text { DPl } \\
\text { dult } \\
960\end{array}$ & $\begin{array}{l}\text { (2) } \\
\text { GDP/ } \\
\text { Adult } \\
1985\end{array}$ & $\begin{array}{l}\text { (3) } \\
\text { Avg } \\
\text { Growth } \\
\text { GDP/ } \\
\text { Adult }\end{array}$ & $\begin{array}{l}(4) \\
\text { Avg } \\
\text { GDP/ } \\
\text { Adult } \\
60-85\end{array}$ & $\begin{array}{l}\text { (5) } \\
\text { Avg } \\
\text { GDP } \\
\text { (Scale) } \\
60-85\end{array}$ & $\begin{array}{l}\text { (6) } \\
\text { Avg So } \\
\text { Invest/ } \\
\text { GDP } \\
60-85\end{array}$ & $\begin{array}{l}\text { (7) } \\
\text { school }\end{array}$ & $\begin{array}{l}\text { (8) } \\
\text { Growt } \\
1960-8 \\
\text { Workin } \\
\text { Age Po }\end{array}$ \\
\hline Asia & Korea, $\mathrm{R}$ & 1285 & 4775 & 0.053 & 3030 & $5.84 E+07$ & 22.37 & 10.2 & 2.7 \\
\hline L & uay & 1951 & 3914 & 0.028 & 2933 & $3.75 E+06$ & 511.70 & & \\
\hline R & Jamaíca & 2726 & 3080 & 0.005 & 2903 & $3.89 E+06$ & 620.64 & 11.2 & 1.6 \\
\hline & Guatemal & 2481 & 3034 & 0.008 & 2758 & $9.77 \mathrm{E}+06$ & 8.81 & 2.4 & 3.1 \\
\hline $\begin{array}{c}\text { Afric } \\
\text { lartile } 3\end{array}$ & Tur & 1623 & 3661 & 0.033 & 2642 & $7.80 E+06$ & $\begin{array}{ll}5 & 13.89\end{array}$ & 4.3 & 2. \\
\hline Lat in & Dominica & 1939 & .3308 & 0.021 & 2624 & $6.95 E+06$ & $5 \quad 17.18$ & 5.8 & 2.9 \\
\hline & Mauritiu & 1973 & 2967 & 0.016 & 2470 & $1.18 \mathrm{E}+06$ & $6 \quad 17.19$ & 3 & 2.6 \\
\hline ic & Botswana & 959 & 3671 & 0.054 & 2315 & $7.77 E+05$ & $5 \quad 28.39$ & 2.9 & 3.2 \\
\hline $\begin{array}{l}A \\
R\end{array}$ & Thailand & 1308 & 3220 & 0.036 & 2264 & $5.13 E+07$ & 718.08 & 4.4 & 3.1 \\
\hline & $\mathrm{Ne}$ & 1781 & 2544 & 0.014 & 2163 & $3.75 E+06$ & $5 \quad 16.29$ & .5 & 2.1 \\
\hline & Sri Lank & 1794 & 2482 & 0.013 & 2138 & $1.42 \mathrm{E}+07$ & 714.82 & .3 & 2.4 \\
\hline & philippi & 1668 & 2430 & 0.015 & 2049 & $5.07 E+07$ & 714.93 & 10.6 & 3 \\
\hline & I va & 2042 & 1997 & -0.001 & 2020 & $5.23 E+06$ & 8.04 & 3.9 & 3.3 \\
\hline & Bol & 1618 & 2055 & 0.010 & 1837 & $5.94 E+06$ & 613.35 & .9 & 2.4 \\
\hline $\begin{array}{l}\text { ic } \\
\text { ic }\end{array}$ & , $\mathrm{P}$ & 1009 & 2624 & 0.038 & 1817 & $1.29 E+06$ & $6 \quad 28.82$ & .8 & 2.4 \\
\hline $\begin{array}{l}\text { ic } \\
\text { ic }\end{array}$ & Mo & 1030 & 2348 & 0.033 & 1689 & $1.60 E+07$ & 8.34 & .6 & $2 \cdot 5$ \\
\hline & bwe & 1187 & 2107 & 0.023 & 1647 & $4.97 E+06$ & 621.12 & 4 & 2.8 \\
\hline & ras & 1430 & 1822 & 0 . & 1626 & 2.76 & $\begin{array}{ll}6 & 13.8\end{array}$ & .7 & $3 \cdot 1$ \\
\hline & $\mathrm{Pa}$ & 10 & 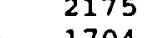 & 0 & $\begin{array}{l}6 \\
5\end{array}$ & $\begin{array}{l}5.86 E+07 \\
6.17 E+06\end{array}$ & $\begin{array}{ll}7 & 12.23 \\
6 & 12.45\end{array}$ & 2.3 & $\begin{array}{r}3 \\
4.3\end{array}$ \\
\hline ic & $\begin{array}{l}\text { Co } \\
\text { oon }\end{array}$ & $\begin{array}{r}1386 \\
889\end{array}$ & $\begin{array}{l}1704 \\
2190\end{array}$ & 0.0036 & 1540 & $5.62 \mathrm{E}+06$ & 512.90 & $\begin{array}{l}2.3 \\
3.4\end{array}$ & $\begin{array}{l}4.3 \\
2.1\end{array}$ \\
\hline c & $\mathrm{Eg}$ & 907 & 2160 & 0.035 & 1534 & $2.93 E+07$ & 716.33 & 3 & $\begin{array}{l}2.1 \\
2.5\end{array}$ \\
\hline & esi & 879 & 2159 & 0.036 & 1519 & $1.00 E+08$ & 313.90 & 4.3 & 1.9 \\
\hline ic & a 1 & 1392 & 1450 & 0.002 & 1421 & $3.65 E+06$ & 9.6 & .7 & 2.3 \\
\hline ic & Ar & 1588 & 1171 & -0.012 & 1380 & $5.48 E+06$ & 5.85 & 1.8 & 2.1 \\
\hline ic & $\mathrm{Za}$ & 1410 & 1217 & -0.00 & 314 & $3.44 E+06$ & 631.75 & 2.4 & 2.7 \\
\hline ic & biq & 142 & 10 & -0. & 1228 & $7.42 \mathrm{E}+06$ & 6.17 & 0.7 & 2.7 \\
\hline & & 1096 & & & 1167 & $2.71 E+06$ & 7.10 & 1.9 & 1.3 \\
\hline la 4 & India & 978 & 1339 & 0.013 & 1159 & $3.48 E+08$ & 816.82 & 5.1 & $2 \cdot 4$ \\
\hline ric & $S$ & 1254 & 1038 & -0.008 & 1146 & $1.05 E+07$ & 713.25 & & \\
\hline & & 94 & 329 & 0. & 137 & $7.57 E+06$ & $5 \quad 17.45$ & 2. & $\begin{array}{l}2.6 \\
3.4\end{array}$ \\
\hline ic & ía & 1055 & 1186 & 0.005 & 1121 & $4.74 \mathrm{E}+07$ & 712.00 & -2 & 2.4 \\
\hline ic & Ber & 1116 & 1071 & -0.002 & 1094 & $1.66 \mathrm{E}+06$ & $6 \quad 10.82$ & 1.8 & 2.4 \\
\hline ric & Madagasc & 1194 & 975 & -0.008 & 1085 & $4.43 E+06$ & 7.12 & 2.6 & 2.2 \\
\hline & Lade & $84 \longrightarrow$ & 1221 & 0.01 & 1034 & $3.71 E+07$ & 6.83 & 3.2 & 2.6 \\
\hline$c$ & $\tan$ & 777 - & 1038 & 0. & 908 & $7.10 E+05$ & $5 \quad 25.62$ & 2 & 2.2 \\
\hline & Lit & 863 & 4 & 0.004 & 904 & $9.46 E+05$ & 521.51 & 2.5 & 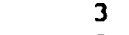 \\
\hline & Nepa 1 & 83 & 974 & 0.006 & 904 & $6.24 E+06$ & 5.95 & 2.3 & \\
\hline & To & 777 & 978 & 0.009 & 878 & $1.25 E+06$ & 615.5 & 2.9 & 2.5 \\
\hline ic & Ghana & 1009 & 727 & -0.01 & 868 & $4.57 E+06$ & 9.12 & 4.7 & 2.3 \\
\hline ic & Central & 838 & 789 & -0.002 & 814 & $9.66 \mathrm{E}+05$ & 510.55 & 1.4 & 1.7 \\
\hline ic & & 90 & 657 & -0 & 779 & $1.59 E+06$ & $6 \quad 13.81$ & 1.1 & 3.1 \\
\hline & & 51 & 1031 & & 774 & $1.24 E+07$ & 711.4 & 3.5 & 1.7 \\
\hline ic & Mali & 737 & 710 & -0.001 & 724 & $91 E+06$ & 7.32 & 2 & 2.2 \\
\hline
\end{tabular}


$A-3$

\begin{tabular}{|c|c|c|c|c|c|c|c|c|c|}
\hline egion & Country & $\begin{array}{l}\text { (1) } \\
\text { GDP/ } \\
\text { Adult } \\
1960\end{array}$ & $\begin{array}{l}\text { (2) } \\
\text { GDP/ } \\
\text { Adult } \\
1985\end{array}$ & $\begin{array}{l}\text { (3) } \\
\text { Avg } \\
\text { Growth } \\
\text { GDP/ } \\
\text { Adult }\end{array}$ & $\begin{array}{l}\text { (4) } \\
\text { Avg } \\
\text { GDP / } \\
\text { Adult } \\
60-85\end{array}$ & $\begin{array}{l}\text { (5) } \\
\text { Avg } \\
\text { GDP } \\
\text { (Scale) } \\
60-85\end{array}$ & $\begin{array}{l}\text { (6) } \\
\text { ivg S } \\
\text { [nvest/ } \\
\text { GDP } \\
50-85\end{array}$ & $\begin{array}{l}\text { (7) } \\
\text { School } \\
\text { ( }\end{array}$ & $\begin{array}{l}\text { (8) } \\
\text { Growth } \\
1960-85 \\
\text { Working } \\
\text { Age Pop }\end{array}$ \\
\hline fric & Burundi & 755 & 663 & -0.005 & 709 & $1.18 E+06$ & 5.12 & 0.4 & 1.7 \\
\hline$\Leftrightarrow$ & Bur & 529 & 857 & 19 & 693 & $1.76 \mathrm{E}+06$ & 12.70 & 0.4 & 0.9 \\
\hline Afric & Niger & 539 & 841 & 0.018 & 690 & $1.79 E+06$ & 510.39 & 0.5 & 2.6 \\
\hline Afric & Chad & 908 & 462 & -0.027 & 685 & $1.62 \mathrm{E}+06$ & 6.99 & 0.4 & 1.9 \\
\hline fric & Sierra L & 511 & 805 & 0.018 & 658 & $1.33 E+06$ & 10.95 & 1.7 & 1.6 \\
\hline Afric & Malawi & 455 & 823 & 0.024 & 639 & $1.77 E+06$ & 513.23 & 0.6 & 2.4 \\
\hline fric & Uganda & 601 & 667 & 0.004 & 634 & $3.39 E+06$ & 4.20 & 1.1 & 3.1 \\
\hline fric & Rwanda & 460 & 696 & 0.017 & 578 & $1.26 \mathrm{E}+06$ & 7.99 & 0.4 & 2.8 \\
\hline ric & Ethiopia & 533 & 608 & 0.005 & 571 & $1.01 E+07$ & 5.48 & 1.1 & 2.3 \\
\hline Afric & Tanzania & 38 & 710 & 0.025 & 547 & $4.61 E+06$ & 18.05 & 0.5 & 2.9 \\
\hline Afric & Zaire & 594 & 412 & -0.015 & 503 & $7.10 E+06$ & 6.60 & 3.6 & 2.4 \\
\hline
\end{tabular}

Notes: Gross domestic product and investment series for all countries are measured in real 1980 international dollars. The data are taken from the Penn World Table (Mark 4) as reported in Heston and summers (1988). 1960 GDP per adult col (1) is the initial income variable used in the convergence equations in this paper. Column (3) is the average growth of GDP per adult over the period 1960-85. It is calculated as the log difference of 1985 and 1960 GDP per adult, divided by 25 . The total growth of GDP per adult over the 1960-85 period is used as the dependent variable in most of the regressions. The above period is urted by average GDP per adult (col (4)) in descending order. It is data are sorted by average GDP per adult (Col (4)) in descendiable (col (5)) is the average of the mean GDP value for the period 1960-85. Column 6 is the average invest calculated as the mean of the investment ratios for each year 1960-85. The

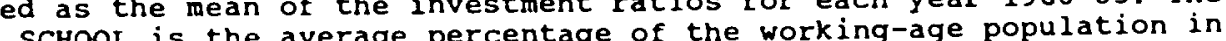
variable SCHOOL is the average percentage of the working-age population in secondary school for the period 1960-85. The school and working age population
data are from Mankiw, Romer and Weil (1985). The working-age population growth rates are averages for the period 1960-85. 


$$
A-4
$$

Estimation of the solow Regidual for the OECD countries:

The ces two factor production function which we use to define output $q$ is: $q=\left[1(\mathrm{pN})^{(-1) / 4}+m K^{(-1))_{0}}\right]^{2 /(-1)}$

where $N$ is the number of people employed and $K$ is the capital stock. 1 and m are distribution parameters in the CES function and $s$ is the estimated alasticity of substitution between labour and capital. $p$ is the labour productivity index for Harrod-neutral technical progress. For estimation purposes we use the time series for output attributable to each employee, calculated by inverting the above CES production function and attributing a sample-average rate of return to the capital stock:

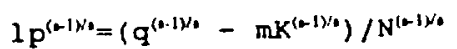

With a Cobb-Douglas production function, this series only differs by a constant term from the total-factor index of technology often referred to as the solow residual.

For the reader interested in how we estimate the parameters of the CES production function, the paper by Helliwell and Chung (1990a) contains a complete appendix on the procedure that we use. The primary sources of the data used for the 19 OECD countries are the national accounts published by the OECD for the industrial countries, converted to common currency using PPP exchange for the industrial countries, converted to common currency and employment data are also mainly from oECD sources. Helliwell and Chung (1990a) outline the assumptions used in the construction of the capital stocks and also provide a detailed listing of the data sources used. 